NBER WORKING PAPER SERIES

\title{
SOURCES OF ADVANTAGEOUS SELECTION: EVIDENCE FROM THE MEDIGAP INSURANCE MARKET
}

\author{
Hanming Fang \\ Michael P. Keane \\ Dan Silverman \\ Working Paper 12289 \\ http://www.nber.org/papers/w12289
NATIONAL BUREAU OF ECONOMIC RESEARCH
1050 Massachusetts Avenue
Cambridge, MA 02138
June 2006

We thank Pierre-Andr e Chiappori, Alessandro Lizzeri, Jim Poterba, Bernard Salani e, Aloysius Siow, and especially Amy Finkelstein, as well as seminar participants at Brown, Concordia, Duke/UNC, Federal Reserve Bank of New York, Queens, Toronto, Virginia, Wharton and Yale for many helpful suggestions. We are grateful to Mike Chernew for the access to, and Tami Swenson for clarification of, the Medicare Current Beneficiary Survey data. All remaining errors are our own. Fang and Silverman gratefully acknowledge financial support from the Economic Research Initiative on the Uninsured. The views expressed herein are those of the author(s) and do not necessarily reflect the views of the National Bureau of Economic Research.

(C2006 by Hanming Fang, Michael P. Keane and Dan Silverman. All rights reserved. Short sections of text, not to exceed two paragraphs, may be quoted without explicit permission provided that full credit, including (c) notice, is given to the source. 
Sources of Advantageous Selection: Evidence from the Medigap Insurance Market Hanming Fang, Michael P. Keane and Dan Silverman

NBER Working Paper No. 12289

June 2006

JEL No. D82, G22, I11

\begin{abstract}
$\underline{\text { ABSTRACT }}$
We provide strong evidence of advantageous selection in the Medigap insurance market, and analyze its sources. Using Medicare Current Beneficiary Survey (MCBS) data, we find that, conditional on controls for the price of Medigap, medical expenditures for senior citizens with Medigap coverage are, on average, about $\$ 4,000$ less than for those without. But, if we condition on health, expenditures for seniors on Medigap are about $\$ 2,000$ more. These two findings can only be reconciled if those with less health expenditure risk are more likely to purchase Medigap, implying advantageous selection. By combining the MCBS and the Health and Retirement Study (HRS), we investigate the sources of this advantageous selection. These include income, education, longevity expectations and financial planing horizons, as well as cognitive ability. Once we condition on all these factors, seniors with higher expected medical expenditure are indeed more likely to purchase Medigap. Surprisingly, risk preferences do not appear to be a source of advantageous selection. But cognitive ability emerges as a particularly important factor, consistent with a view that many senior citizens have difficulty understanding Medicare and Medigap rules.
\end{abstract}

Hanming Fang

Yale University

Department of Economics

37 Hillhouse Avenue

P.O. Box 208264

New Haven, CT 06520-8264

and NBER

hanming.fang@yale.edu

Michael P. Keane

Department of Economics

Yale University

Box 208264

New Haven, CT 06520-8264

michael.keane@yale.edu

Dan Silverman

Institute for Advanced Study

Einstein Drive

Princeton, NJ 08540

and NBER

dansilv@umich.edu 


\section{Introduction}

Asymmetric information is central to modern economic models of insurance pioneered by Arrow (1963) and Pauly (1974). The classic equilibrium models developed by Rothschild and Stiglitz (1976) and Wilson (1977) assume that potential insurance buyers have one-dimensional private information regarding their risk type. They choose from a menu of contracts, specifying the price and amount of coverage, the one best suited to their type. These simple models predict a positive correlation between insurance coverage and ex post realizations of loss. The reason is simply ex ante adverse selection: the "bad risks" (i.e., those relatively likely to suffer a loss) have an incentive to buy more insurance. Allowing for ex post moral hazard only strengthens the positive correlation between coverage and ex post loss. This "positive correlation property" of classic asymmetric information models (see Chiappori and Salanié 2000) forms the basis for empirical tests of asymmetric information in several recent papers 1 Interestingly, these papers, which examine a variety of important insurance markets, generally fail to find empirical support for the positive correlation property (see Section 2 for details).

Indeed, it is often found that, conditional on pricing information, those who buy more insurance tend to be relatively good risks - a phenomenon that has been called "advantageous selection." Some researchers have speculated that multi-dimensional private information can explain this phenomenon $2^{2}$ For example, de Meza and Webb (2001), postulate that individuals have private information about both their risk type and their risk aversion. Selection based on risk aversion is advantageous if: (1) the more risk averse buy more insurance coverage; and (2) the more risk averse have lower risks. Then, failure to condition on risk aversion may mask the expected positive correlation between insurance coverage and ex post risk that exists in one-dimensional models $3_{3}^{3}$ Of course, while the prior literature has emphasized risk aversion as the prime suspect 4 it is not the only potential source of advantageous selection. More generally, selection based on any private information item $\gamma$ is advantageous if $\gamma$ is positively correlated with insurance coverage but negatively

\footnotetext{
${ }^{1}$ Chiappori, Jullien, Salanié and Salanié (2005) generalize this empirical prediction to a large class of models where the insurance market is competitive and the risk aversion of the insured is public knowledge, assuming a suitably modified notion of positive correlation between risk occurrence and coverage. Chiappori (2000) provides a useful survey of the theoretical and empirical literature up to that date.

${ }^{2}$ See, e.g., the concluding discussions in Chiappori and Salanié (2001) and Finkelstein and Poterba (2004).

${ }^{3}$ The first verbal description of this phenomenon in the economics literature appears to be Hemenway (1990, 1992), who used the term "propitious selection."

${ }^{4}$ The notable exception is Finkelstein and McGarry (2006) who also found advantageous selection on wealth in their study of the long term care insurance market.
} 
correlated with risk (see Section 3 for details). Furthermore, $\gamma$ need not be private information, but could also include observables that insurers are not permitted to use in setting prices.

While prior work has speculated that advantageous selection based on unobservables accounts for the empirical failure of the "positive correlation property," it has not provided direct evidence to support this conjecture $5^{5}$ Nor has it provided direct evidence on the source (or sources) of advantageous selection, be it risk aversion and/or something else.

In this paper, we study the advantageous selection phenomenon using data from the Medicare supplemental or "Medigap" insurance market. A "Medigap" policy is health insurance sold by a private insurer to fill "gaps" in coverage of the basic Medicare plan (e.g. co-pays, prescription drugs) ${ }^{6}$ We show that the Medigap market is characterized by advantageous selection: conditional on the determinants of price, those who purchase supplemental insurance tend to be healthier than those who do not. More importantly, we go beyond prior research to investigate several potential sources of this advantageous selection. We find that these sources include standard factors such as income, education, longevity expectations and financial planing horizons, as well as less conventionally modelled variables including cognitive ability and financial numeracy. Once we condition on all these factors, individuals with higher expected medical expenditures are indeed more likely to purchase Medigap insurance.

Interestingly, while the theoretical literature has emphasized risk preferences as a potential source of advantageous selection, we find little evidence in support of that hypothesis. Direct measures of risk tolerance are significant predictors of Medigap insurance purchase but do not contribute much to advantageous selection $\sqrt[7]{7}$ Rather, cognitive ability and income emerge as far more important sources of advantageous selection.

Our finding that cognitive ability is an important source of advantageous selection is consistent with earlier literature showing that many senior citizens have difficulty understanding Medicare and Medigap rules (see, e.g., Cafferata (1984), McCall et al. (1986), Davidson et al. (1992), Harris and Keane (1999)). In particular, it appears that many fail to understand Medicare cost sharing requirements. There is also a literature showing that many consumers have difficulty understanding

\footnotetext{
${ }^{5}$ Finkelstein and McGarry (2006), which we discuss in more detail in Section 2 use preventive health care as a proxy for risk preference, and find indirect evidence of advantageous selection based on risk preference.

${ }^{6}$ See Section 4 for more details about the Medicare program and the Medigap insurance market.

${ }^{7}$ In this regard, our results are consistent with Cohen and Einav (2005) who estimate a structural model of automobile insurance deductible choice, and use it to infer both accident risk and risk aversion. They find risk type is positively correlated with risk aversion, contrary to what is required for risk aversion to be a source of advantageous selection. The evidence in Cohen and Einav is, however, indirect, as neither risk or risk aversion are directly measured.
} 
health insurance plans more generally. See, e.g., Gibbs et al. (1996), Isaacs (1996), Tumlinson et al. (1997), Cunningham et al. (2001). Our results imply that senior citizens with relatively low cognitive ability also tend to have relatively high health expenditure risk and low probability of buying Medigap (even conditional on income and price). This may suggest a role for educational interventions to facilitate choice (see, e.g., Harris (2002)).

The Medigap market is ideal for studying advantageous selection because the coverage and pricing of Medigap policies are highly regulated by the U.S. government. First, in all but three States, insurance companies can only sell ten standardized Medigap policies. Second, within the six month Medigap open enrollment period - which starts when an individual is both older than 65 and enrolled in Medicare Part B - an insurer cannot deny Medigap coverage, or place conditions on a policy, or charge more for pre-existing health conditions. Indeed Robst (2001) finds that the average Medigap premium an individual faces depends almost exclusively on his/her State of residence, age and gender. Thus, we do not need to worry that the sources of advantageous selection we have identified (e.g., income, cognition, etc.) might influence prices because they are potentially observed by insurers. 8

Another key feature of the Medigap market is that it is intimately linked to the Medicare program, so one can obtain detailed administrative data on diagnoses, treatments and expenditures. We exploit this link and use in our analysis the Medicare Current Beneficiary Survey (MCBS), which combines survey data and Medicare administrative records. The Medicare administrative data on medical expenditure provide perhaps the most accurate measure of health expenditure risk of any commonly available data set. Though the MCBS itself does not contain detailed information about risk aversion and other potential sources of advantageous selection, the Health and Retirement Study (HRS), a longitudinal data set covering a large sample of the Medicare eligible population, has information about such variables. Our empirical strategy uses the MCBS and HRS jointly to examine the sources of advantageous selection.

The remainder of the paper is structured as follows. Section 2 reviews related literature; Section 3 presents a simple theoretical framework to illustrate the idea of advantageous selection; Section 4 provides some detailed background about Medicare and the Medigap insurance market; Section 5 describes the MCBS and HRS data sets used in our analysis; Section 6 provides direct and indirect evidence of advantageous selection using the MCBS data; Section 7 examines the sources

\footnotetext{
${ }^{8}$ As shown in the theoretical analysis of Julien, Salanié and Salanié (2005), the non-competitiveness of the Medigap insurance market is a necessary condition for the multi-dimensional private information to manifest itself in terms of a non-positive correlation between ex post risk and coverage.
} 
of advantageous selection by combining the MCBS and HRS, and presents our main results; Section 8 presents several robustness checks on our results; Section 9 briefly discusses the conditions under which our estimates also provide a lower bound on the magnitude of moral hazard (or price effect) of Medigap insurance coverage; and finally, Section 10 concludes.

\section{Related Literature}

Empirical Tests for the Presence of Asymmetric Information. Standard equilibrium models of insurance markets predict a positive correlation between insurance coverage and ex post risk (Chiappori, Jullien, Salanié and Salanié 2005). This positive correlation property has been tested in several recent studies, for a variety of markets. Cawley and Philipson (1999) use four data sources including the HRS and the Asset and Health Dynamics Among the Oldest Old (AHEAD) to test for positive correlation between self-perceived or objective mortality risk and the probability of purchasing life insurance. To the contrary, they find the mortality rate of U.S. males who purchase life insurance is below that of the uninsured, even when controlling for many factors such as income that may be correlated with life expectancy.

The evidence from the auto insurance market is more ambiguous. Chiappori and Salanié (2000) show that accident rates are lower for young French drivers who choose comprehensive automobile insurance than for those opting for the legal minimum coverage, even after controlling for observable characteristics known to automobile insurers (though the difference is not statistically significant). On the other hand, there is a literature that supports the presence of adverse selection in the choice of contractual forms, including deductibles and co-payments etc. For example, Puelz and Snow (1994) argued, in the context of automobile collision insurance, that in an adverse selection equilibrium, individuals with lower risk will choose a contract with a higher deductible, and contracts with higher deductibles should be associated with lower average prices for coverage. They find evidence in support of each of these predictions using individual data from an automobile insurer in Georgia.$^{9}$ Similarly, Cohen (2005), using data from Israel, finds that new auto insurance customers choosing a low deductible tend to have more accidents, leading to higher total losses to the insurer 10

\footnotetext{
${ }^{9}$ However, see Chiappori and Salanié (2000) and Dionne, Gouriéroux and Vanasse (2001) for some criticisms of the Puelz and Snow study.

${ }^{10}$ Moreover, she finds this correlation exists among experienced new customers (those with 3 or more years of driving experience), but not among inexperienced new customers (those with little or no driving experience). This suggests learning is involved in the origin of private information.
} 
Cardon and Hendel (2001) use a different approach to test for information asymmetries in health insurance markets. They estimate a structural model of health insurance and health care choices using data on single individuals from the National Medical Expenditure Survey. They find that estimated price and income elasticities, as well as demographic differences, can explain the expenditure gap between the insured and the uninsured. Thus they judge the role of adverse selection to be economically insignificant 11

Finkelstein and Poterba (2004) use a unique individual level data set on annuities from the U.K. and find systematic relationships between ex post mortality and annuity characteristics, such as the timing of payments and the possibility of payments to the annuitants' estate. But they do not find evidence of substantive mortality differences by annuity size.

Finkelstein and McGarry (2006). Our paper is most closely related to recent work by Finkelstein and McGarry (2006), who study selection based on multi-dimensional private information in the long-term care (LTC) insurance market. Using the AHEAD data they find a negative (though statistically insignificant) correlation between LTC coverage in 1995 and use of nursing home care in the period between 1995-2000, even after controlling for insurers' assessment of a person's risk type - (weakly) suggesting the presence of advantageous selection. However, the 1995 AHEAD also contains the subjective probability assessment "What do you think are the chances that you will move to a nursing home in the next five years?" This variable is known by the insured and the econometrician, but unobserved by the insurer, so it cannot be used in setting prices. Finkelstein and McGarry (2006) find this subjective risk assessment is positively correlated with both LTC coverage and nursing home use in 1995-2000, even after controlling for insurers' risk assessment, suggesting the presence of adverse selection based on private information about risk type ${ }^{12}$

What makes the Finkelstein and McGarry (2006) paper similar to ours is that they develop a proxy for risk aversion, using information on whether respondents undertake various types of preventive health care ${ }^{13}$ They find that people who are more risk averse by this measure are

\footnotetext{
${ }^{11}$ In their structural model, Cardon and Hendel (2001) assume that individuals have identical preferences.

${ }^{12}$ Recently, Finkelstein and Poterba (2006) proposed such use of characteristics of insurance buyers that are observable to the econometrician but not used by insurers in setting prices as a general strategy to test for asymmetric information in insurance markets. If one can find one or more such observables that are correlated with both the insurance coverage and the risk occurrence, then one rejects the null hypothesis of symmetric information.

${ }^{13}$ The potential preventive health care measures they include are: whether the individual had a flu shot, had a blood test for cholesterol, checked her breast for lumps monthly, had a mammogram or breast x-ray, had a Pap smear and had a prostate screen.
} 
both more likely to own LTC insurance and less likely to enter a nursing home - consistent with advantageous selection based on risk aversion.

To summarize, Finkelstein and McGarry (2006) find that the overall correlation between LTC insurance coverage and use of long-term care is negative but insignificant. They conclude that multidimensional private information explains this result, since they find adverse selection based on the subjective risk assessment and advantageous selection based on their proxy for risk aversion, and it seems these two factors may roughly cancel on net.

Our paper complements and extends Finkelstein and McGarry (2006) in several ways. First, we examine a much larger insurance market, the Medigap market. More than half the over age 65 respondents in our HRS data purchased a Medigap policy. In contrast, the LTC insurance market is very small (only about 10 percent of the elderly in the AHEAD had LTC insurance). Besides being a very large and important market, we feel the Medigap market has several important advantages for studying asymmetric information.

First, studying the Medigap market allows us to employ a different method of inference about the presence of advantageous selection. The key point is that regulation effectively precludes price discrimination on the basis of health risk. Thus, we can consider the effect on the estimated relationship between Medigap coverage and ex-post risk of conditioning on a rich set of health information that is, by law, private to consumers. This gives us a much richer set of "private" risk measures than the single subjective risk assessment used by Finkelstein and McGarry (2006).

Second, we examine not just one possible source of advantageous selection (i.e., risk aversion), but several other potential sources as well. For this purpose, we use HRS information on other objects of special theoretical interest such as longevity expectations, planning horizons, cognition and financial numeracy, etc. Third, rather than using behavioral proxies for risk aversion, we exploit the direct measures of risk aversion contained in the HRS.

Finally, the Medigap market has the key virtue that ex post health expenditure risk (i.e., health expenditure itself) can be quite accurately measured using the MCBS. This dataset contains comprehensive health expenditure data for a large sample of the entire Medicare population, from age 65 until death. It also contains very extensive health measures, enabling one to form accurate measures of ex post expenditure conditional on age and health 14

\footnotetext{
${ }^{14}$ In contrast, available LTC data sets do not contain large samples of respondents at the oldest ages, when many episodes of nursing home care occur. Since many nursing home admissions occur in the few years/months before death, the best measure of ex post risk for LTC is whether one eventually uses nursing home care prior to death, not whether one uses it over some particular time period. Since many of the respondents in the AHEAD data used by Finkelstein and McGarry (2006) are still alive, their measure of ex post risk - whether the respondent used a nursing
} 
Literature on Adverse Selection in the Medigap Market. Our paper is also related to a literature that looks for evidence of adverse selection in the Medigap market. Wolfe and Goddeeris (1991) examine this issue using data from the Retirement History Survey, a longitudinal survey of recent retirees conducted by Social Security Administration between 1969 and 1979. They used self reported health and self reported expenditure measures, the latter including total medical bills for hospital, physician and prescription expenditures, including any amount paid by insurance. They found that respondents with better self-reported health were more likely to purchase supplemental private insurance. But those with private insurance also incurred higher expenditures on hospital stays, physician care and prescription drugs (though this difference was statistically insignificant).

Hurd and McGarry (1997) used the first wave of AHEAD to examine how health insurance influences the use of health care services by the elderly. They found that those with more comprehensive insurance tend to use more health care services (as measured by number of hospital and doctor visits), controlling for self-reported health indicators ${ }^{15}$ However, they also found little relationship between observable health measures and either the propensity to hold or purchase health insurance, indicating little importance of adverse selection.

Khandker and McCormack (1996) estimated multinomial logit models of insurance choice and found that individuals reporting better health were significantly more likely to enroll in private supplemental plans. This is consistent with advantageous selection, although self reported health does not necessarily correspond to ex post expenditure.

In contrast, Ettner (1997), using MCBS 1991, found little evidence of variation in the probability of purchasing private insurance by health status 16 She also found that Medicare beneficiaries with supplemental policies had higher total Medicare and physician expenditures than those with employer-provided policies, even after controlling for observable differences. She interprets this as evidence of adverse selection under the assumption that selection into employer provided coverage is random. We view this assumption as implausible. Moreover, those with employer-sponsored health insurance may be subject to different rules regarding whether Medicare is the primary payer for various services. Such issues are important because Ettner (1997) examined only Medicare reimbursed expenditure.

home between 1995 and 2000 - may be relatively incomplete. The AHEAD sample represents the population born before 1924, and who were at least 76 by the year 2000; but many are quite far from their time of death. According to life-table estimates, those alive at age 75 in 2000, had on average 11.4 more years to live (Vital Statistics, 2004).

${ }^{15}$ They did not report results without controlling for measured health.

${ }^{16}$ Lillard and Rogowski (1995), using the Panel Study of Income Dynamics (PSID), also found little evidence of adverse selection for supplemental insurance. 
Finally, Khandker and McCormack (1999), using MCBS 1991 and 1993, found that those with supplemental private insurance tended to incur higher levels of Medicare reimbursed spending, particularly Part B services. However, because Medigap plans cover Medicare co-pays, they reduce the out-of-pocket price of Medicare covered services. Thus, it is possible that those with Medigap incur higher Medicare reimbursed expenditures, while nonetheless incurring less total health care spending. (Indeed, Section 6.1 provides evidence consistent with this view.) Conversely, those with basic Medicare alone may incur more total expenditures, despite smaller Medicare reimbursed expenditures, because they spend more out of pocket. Thus, we would argue that, to study adverse selection in Medigap, a better measure of health expenditure risk is total medical expenditure, not just expenditure reimbursed by Medicare or Medigap 17

\section{Multi-dimensional Private Information and Advantageous Se- lection}

It is now well understood that, given multi-dimensional private information, the correlation between ex post risk realizations and coverage may be negative, zero, or positive - see, Henmenway (1990, 1992), de Meza and Webb (2001), Araujo and Moreira (2001) and Jullien, Salanié and Salanié (2005). These papers all focus on private information about risk aversion as the source of advantageous selection. In this section, we first follow the literature and illustrate this idea using risk aversion in a partial equilibrium example; then, anticipating our main empirical focus, we expand our definition of advantageous selection to include selection based on other types of private information.

Risk Aversion as the Source of Advantageous Selection Consider an individual over age 65 (so she has basic Medicare as a baseline level of coverage). She has a constant relative risk aversion utility function

$$
u(y)=\frac{y^{1-\gamma}}{1-\gamma}
$$

where $\gamma$ is the relative risk aversion parameter. She has wealth $Y>0$, and faces a risk of incurring a health expenditure shock (over and above what is covered by basic Medicare) of $L>0$ with

\footnotetext{
${ }^{17}$ Unfortunately, the waves of the MCBS data used in Khandker and McCormack's (1999) analysis only contained Medicare claim data, but did not contain information about total health cost, including beneficiary out-of-pocket cost as well as expenses paid by supplementary insurers. We are grateful to Tami Swenson for the clarification on these data issues.
} 


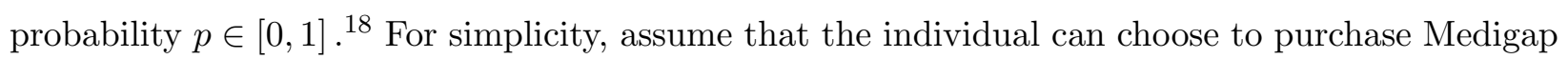
insurance at a premium $m$ that will reduce the out-of-pocket expenditure to 0. Her expected utilities from buying and not buying Medigap are respectively given by

$$
\begin{aligned}
V_{B}(p, \gamma) & =u(Y-m)+e \\
V_{N}(p, \gamma) & =p u(Y-L)+(1-p) u(Y)
\end{aligned}
$$

where $e$ is a fixed cost of buying Medigap (i.e., the time and psychic costs of applying), that has a logistic distribution in the population, independent of $p$ and $\gamma$. The probability the individual purchases Medigap is then given by the logit expression:

$$
Q(p, \gamma)=\frac{\exp \left[V_{B}(p, \gamma)\right]}{\exp \left[V_{B}(p, \gamma)\right]+\exp \left[V_{N}(p, \gamma)\right]}
$$

Simple algebra shows that $Q(p, \gamma)$ is increasing in $p$ and $\gamma{ }^{19}$ That is, more risky and more risk averse individuals are more likely to purchase Medigap.

Now suppose that in the population there is a joint distribution over individuals' private types $(p, \gamma)$ given by $F$, and let the CDF of risk aversion conditional on risk type $p$ be $F_{\gamma \mid p}(\cdot \mid \cdot)$. If we do not control for risk aversion $\gamma$ and look only at the relationship between risk-type $p$ and the probability of purchasing Medigap, we obtain the marginal probability expression:

$$
\tilde{Q}(p)=\int Q(p, \gamma) d F_{\gamma \mid p}(\gamma \mid p)
$$

If $p$ and $\gamma$ are negatively correlated, then $\tilde{Q}(p)$ may or may not increase in $p$.

We can also compare the average health shock risk $p$ for those with and without Medigap insurance. The average risk among those with Medigap insurance is given by

$$
A_{B}=\frac{\int Q(p, \gamma) p d F(p, \gamma)}{\int Q(p, \gamma) d F(p, \gamma)}
$$

where the denominator is the measure of individuals who purchase Medigap, and the numerator is the expected number of health shocks that occur to those who purchase Medigap. Similarly, the

\footnotetext{
${ }^{18}$ We assume away the price effect, also called "moral hazard" as in Cutler and Zeckhauser (1999), by assuming the expenditure level $L$ does not depend on health insurance status.

${ }^{19}$ Note that, the sign of $\partial Q / \partial p$ is the same as the signs of $\partial\left(V_{B}-V_{N}\right) / \partial p$, which is given by:

$$
\frac{\partial\left(V_{B}-V_{N}\right)}{\partial p}=u(Y)-u(Y-L)>0
$$

To show that $Q(p, \gamma)$ is increasing in $\gamma$, it is easier to use the fact that, for any $\gamma^{\prime}>\gamma$, there exists a strictly concave and increasing function $v(\cdot)$ such that $u\left(y ; \gamma^{\prime}\right) \equiv v(u(y ; \gamma))$.
} 
average risk among those without Medigap is

$$
A_{N}=\frac{\int[1-Q(p, \gamma)] p d F(p, \gamma)}{\int[1-Q(p, \gamma)] d F(p, \gamma)}
$$

Chiappori and Salanié's (2000) test for asymmetric information is a test of whether $A_{B}>A_{N}$. However, if $p$ and $\gamma$ are negatively correlated, it is possible that $A_{B} \leq A_{N}$ despite the presence of asymmetric information.

The above example is merely illustrative, as we only analyze individuals' insurance purchase decisions assuming a particular equilibrium (i.e., a particular menu of insurance options), and do not analyze the full equilibrium in which insurance companies may compete by offering different insurance contracts.$^{20}$ However, this simple example captures the idea that, when individuals differ in both risk type and risk aversion, it is possible that those who purchase more coverage may on average be lower risk (if there is negative correlation between risk aversion and risk type).

Sources of Advantageous Selection: General Discussion The above illustration showed how private information about risk aversion can be a source of advantageous selection into insurance. We will now generalize this concept. For this purpose, we again let $p$ denote the probability of a health expenditure shock. But we now interpret $\gamma$ as any private information that may affect agents' probability of purchasing Medigap $Q(p, \gamma)$. Now instead of deriving $Q(p, \gamma)$ explicitly as we did when $\gamma$ was interpreted as risk aversion, we take the probability of Medigap purchase $Q(p, \gamma)$ as the reduced-form entity of focus. Viewed from this perspective, we state the general properties for a private information item $\gamma$ to act as a source of advantageous selection as follows:

Property 1: $\gamma$ is positively correlated with insurance coverage, i.e., $Q(p, \gamma)$ is increasing in $\gamma$;

Property 2: $\gamma$ is negatively correlated with risk $p$.

Under these two conditions, the average probability of insurance purchase for a given risk type $p$, namely $\tilde{Q}(p)$ as defined in (2), may not be monotonic in $p$; and the ranking of $A_{B}$ and $A_{N}$, defined respectively by (3) and (4), can go either way. It is important to emphasize the assumed negative correlation between $\gamma$ and risk $p$ may arise either exogenously or endogenously (in the

\footnotetext{
${ }^{20}$ We refer the reader to Julien, Salanié and Salanié (2005) for a formal equilibrium analysis of the case when the insurance market is not competitive, and Chiappori, Julien, Salanié and Salanié (2005) for the case when the market is competitive. The latter paper shows that, when the insurance market is competitive in the sense that profits are not increasing in coverage, a suitably modified version of the positive correlation property still holds even with multi-dimensional private information.
} 
sense that the would-be-insured with a higher $\gamma$ may take an action to reduce $p$ ). For our purpose this distinction is unimportant 21

In our empirical analysis, we first provide, in Section 6, evidence that is akin to " $A_{B}<A_{N}$," that is, the health risk occurrence for those with Medigap insurance is lower than those without Medigap insurance, suggesting the existence of advantageous selection. Then in Section 7, we examine the sources of advantageous selection, that is, we look for elements of $\gamma$ that may account for the earlier finding that $A_{B}<A_{N}$.

\section{Background on Medicare and Medigap}

\subsection{Medicare}

Medicare is the primary health insurance program for most seniors in the United States. All Americans age 65 and older who have, or whose spouses have, paid Medicare taxes for more than 40 quarters are eligible. The original Medicare Plan consisted of two parts 22 Part A, the hospital insurance program, covers inpatient hospital, skilled nursing facility, and some home health care. Almost all retirees are automatically enrolled in Part A when they turn 65 and there are no premiums paid for this coverage. For the first 60 days of a hospital stay, Medicare pays all covered costs except a deductible, which equalled $\$ 912$ in 2005. For days 61 through 90 Medicare requires a co-pay that was $\$ 228$ per day in 2005 . For days $91-150$ this co-pay rose to $\$ 456$ per day. Hospital stays beyond 150 days are not covered at all by Medicare. For "skilled nursing facility" care, the coinsurance amount is about $\$ 114$ per day for days 21 through 100 each benefit period, but no coverage is provided beyond the 100th day in the benefit period 23 That is, Medicare covers short nursing home stays (up to 100 days) for acute episodes, but does not cover long term care.

Medicare Part B (also called Medicare Insurance) covers Medicare eligible physician services, outpatient hospital services, certain home health services, and durable medical equipment. Part B enrollees have to pay a monthly premium, which was $\$ 67$ in 2004 . Almost all people choose

\footnotetext{
${ }^{21}$ See Culter, Finkelstein and McGarry (2006) for a simple model in which more risk averse individuals take actions to reduce risk, thus endogenously generating a negative correlation between risk aversion and risk.

${ }^{22}$ For details, see Centers for Medicare and Medicaid Services (2005), pages 55-64. The basic Medicare plan is available everywhere in the country. Some areas also offer what are now called Medicare Advantage Plans, which are managed care plans (either HMOs or PPOs, i.e., preferred provider organizations). In 2001, approximately 15\% of Medicare beneficiaries were enrolled in such Medicare HMOs. See Keane (2004) for more discussion.

${ }^{23}$ Note that a skilled nursing facility is a nursing home. It provides both long term care and short term care while a person recovers from an acute episode.
} 
to enroll in Part B when they turn $6 5 \longdiv { 2 4 }$ Under Part B, individuals were responsible for a $\$ 110$ deductible in 2005 and face a $20 \%$ co-pay payment for all Medicare-approved services after exceeding the deductible. Until the recent introduction of "Part D," which provides limited drug coverage, Medicare did not cover prescription drugs.

\section{$4.2 \quad$ Medigap}

As is clear from above, Medicare leaves seniors at significant risk of health care expenditures. To insure Medicare beneficiaries against some of that risk, private insurance companies sell "Medigap" policies that cover some of the co-pays, deductibles and uncovered expenses, i.e. the "gaps," in the basic Medicare plan. Since 1990, by Federal law, Medigap policies are standardized into ten plans, "A" through "J," each representing a different constellation of benefits. The basic plan, A, covers all co-pays for hospital stays longer than 60 days, and all co-pays for physician visits and outpatient care (but not the deductible). All other plans offer these basic benefits, and more. Plan B, for example, also covers the deductible (\$912 in 2005) for hospital stays shorter than 60 days; Plan C, which is the most popular, also covers co-pays for skilled nursing facilities, the Medicare Part B deductible and provides foreign travel emergency coverage. Plan $\mathrm{J}$ adds to this, among other things, prescription drug benefits (with a $\$ 3000$ annual limit in 2004). While not all Medigap policies are offered in every state, almost every state has a provider which offers the basic plan.25 If an insurer offers any Medigap policy, by law it must offer at least the basic plan.

In addition to being regulated with respect to quality, Medigap pricing and coverage are regulated in ways that tend to amplify the asymmetries of information favoring the insured. Most important, Medigap policies are required by law to have an open enrollment period. This six month open enrolment period begins after the first day of the first month an individual is both age 65 or older and enrolled in Medicare Part B. During this period, insurers cannot deny Medigap coverage, delay coverage, or price coverage based on pre-existing conditions 26 Instead, during open enrollment, insurers effectively price only on age, gender and state of residence ${ }^{27}$ Moreover, these

\footnotetext{
${ }^{24} \mathrm{~A}$ person is automatically enrolled at age 65 if they have previously applied for Social Security Old Age Benefits.

${ }^{25}$ The exceptions are Massachusetts, Minnesota and Wisconsin which have received waivers that allow them to offer somewhat different standardized plans.

${ }^{26}$ Moreover, even after open enrollment, so long as the would-be insured has had Medigap coverage for the past 6 months, enrollment in a different plan offered by the same company is guaranteed by law. When a consumer does switch Medigap plans, the price of the policy may depend on the age at purchase, but coverage cannot be denied.

${ }^{27}$ Some insurance companies offer menus of Medigap policy options that may help to discriminate among those with varying health risks. To our knowledge, the pricing comes in only three forms: 1) "age-issued policies" with a
} 
insurance policies are required by law to be guaranteed renewable. That is, beneficiaries may not be dropped from policies so long as they continue the timely payment of the contracted premiums.

It is also important to note that in some (mostly urban) areas, participants of both Medicare A and B may enroll in Medicare HMOs, which may or may not charge an extra premium. About 60 percent of the Medicare HMO enrollees do not pay an extra premium. Rather, they exchange restrictions on their choices for medical treatment for additional coverage similar to that provided by typical Medigap policies ${ }^{28}$ For this reason, they are discouraged, though not precluded, from purchasing additional Medigap insurance policies ${ }^{29}$ Participation in a Medicare HMO is not restricted by a previous lapse in coverage, unlike Medigap.

\section{Data}

\subsection{Medicare Current Beneficiary Survey (MCBS)}

Our analysis relies on two large data sets, the MCBS and HRS. The MCBS began in September 1991, and is a continuous panel survey of a nationally representative sample of the Medicare population 30 Beneficiaries sampled from Medicare enrollment files (or appropriate proxies) are interviewed in person, three times a year, using computer-assisted personal interviewing. All the MCBS survey data are linked to Medicare claims and other administrative data. The final file consists of survey, administrative, and claims data, and thus provides a comprehensive view of respondents' heath care costs and use.

The central goal of the MCBS is to determine expenditures and sources of payment for all services used by Medicare beneficiaries, including co-payments, deductibles, and uncovered services. This is important, since our focus is on the total health expenditure, i.e. the combined expenditures

flat premium that depends only on inflation and age at the date of purchase, 2) "age-attained policies" that have a premium that starts lower than age-issued policies and rises on a predictable schedule as the beneficiary ages, and 3) "community rated" policies whose premiums do not depend either on age at purchase or age attained.

${ }^{28}$ There is substantial evidence of favorable selection into Medicare HMOs (see Keane (2004) for a survey). There is a strong consensus in the literature that this selection - rather than greater efficiency in providing services - is the primary reason they have lower per patient costs than basic Medicare

${ }^{29}$ See page 5 of Center for Midicare and Medicaid Services (2004), which states: "If you're in a Medicare Advantage Plan, you don't need a Medigap policy because Medicare Advantage Plans generally cover many of the same benefits that a Medigap policy would cover, like extra days in the hospital after you used the number of days that Medicare pays for."

${ }^{30}$ See http://www.cms.hhs.gov/mcbs/ for more details. A supplemental sample is added annually in the September-December round to replenish sample cells depleted by refusals and death. 
that were covered by Medicare, other public insurance, private insurance, or paid out-of-pocket. In addition, the MCBS also contains extensive information on the health and demographics of respondents, and whether respondents have supplemental insurance. The Data Appendix provides a detailed description of how the variables used in our analysis are constructed.

An important problem we confront in our empirical analysis is that the MCBS does not contain information on many potential sources of advantageous selection. Conversely, the HRS does not contain information on health expenditures. Thus, our strategy is to use the MCBS to estimate the relationship between total health expenditure and a rich set of health variables. We then use this estimated relationship to form expected health expenditures, $\hat{E}_{i}$, for each HRS respondent. We discuss the imputation procedure in Section 7.1 .

\subsection{Health and Retirement Study (HRS)}

The HRS began as a panel survey of a nationally representative sample of people aged 51 to 61 in 1992, including their spouses, with oversamples of blacks, hispanics and residents of Florida. This original cohort of 12,654 respondents has been re-interviewed every other year since. In 1998 the sample was supplemented with both older and younger cohorts. Our interest in those over age 65 leads us to limit our analysis to health and insurance data from the 2000 and 2002 waves of the original HRS, the latest years for which a final version of the data is available 31

The HRS is particularly well-suited to a study of advantageous selection in Medigap insurance. It contains detailed information about current and past health status of respondents, along with rich data on their insurance choices and health care costs. The health information includes both self-reported health and a very large set of objective measures, such as diseases diagnosed, and a list of activities the respondent has difficulty performing 32 The insurance data include information on where the insurance was acquired, its premiums, and its coverage. A detailed description of the health and insurance information that we use is provided in the Data Appendix.

The HRS also contains high quality information about economic and demographic variables, including education, income, wealth and cognition. In addition, the HRS is distinctive in its attention to variables central to economic theory, including measures of risk aversion, longevity

\footnotetext{
${ }^{31}$ Because we use only the 2000 and 2002 waves of the HRS, we only use the 2000 and 2001 waves of the MCBS in our main analysis, though we use lagged health measures from the 1999 MCBS in several specification checks.

${ }^{32}$ For our purposes, it is important that the health information contained in the HRS and MCBS be very similar. This is crucial if we are to use the MCBS data to impute expected expenditures of HRS respondents, as we describe in Section 7.1 .
} 
expectations, and financial planning horizons. The following sections describe these theoretically important measures in greater detail.

\subsubsection{Measures of Risk Preference}

Risk preferences are central to theories of advantageous selection. Beginning in the first wave in 1992, the HRS asked (subsamples of) respondents a series of questions regarding their risk attitudes. These respondents were first asked the following question:

"Suppose that you are the only income earner in the family, and you have a good job guaranteed to give you your current (family) income every year for life. You are given the opportunity to take a new and equally good job, with a 50-50 chance it will double your (family) income and a 50-50 chance that it will cut your (family) income by a third. Would you take the new job?"

If the answer to the first question is "yes," the interviewer continues with the following question:

"Suppose the chances were 50-50 that it would double your (family) income, and 50-50 that it would cut it in half. Would you still take the new job?"

But, if the answer to the first question is "no," the interviewer instead continues with the question:

"Suppose the chances were 50-50 that it would double your (family) income and 50-50 that it would cut it by 20 percent. Would you then take the new job?"

The responses to these questions place respondents into four, ordered risk categories: e.g., a person who says "no" to both questions is in category I (unwilling to risk any income cuts), while a person who says "yes" to both questions is in category IV (willing to risk a $50 \%$ cut in income). In Wave 2 , a randomly selected sub-sample answered the same sequence of questions, supplemented to include jobs with risks of $10 \%$ and $75 \%$ declines in income.

A number of studies have used these measures of risk preferences and found them to be significant predictors of risk-taking behavior both in the HRS and in the Panel Study of Income Dynamics. See, for example, Barsky et al. (1997) on smoking, drinking and insurance purchase, Lusardi (1998) on wealth accumulation, Charles and Hurst (2003) and Kimball et al. (2005) on portfolio choice, Kan (2003) on residential and job mobility, and Schmidt (2006) on the timing of fertility and marriage. Assuming that an individual's responses to these hypothetical income gambles are error-prone reflections of his/her fixed, constant relative risk aversion preferences, Kimball 
et al. (2005) estimate the risk tolerance for each respondent in the HRS by maximum likelihood. In the bulk of our analysis, we use their estimates to form our measures of risk aversion (see their Table 6).

\subsubsection{Expectations and Planning Horizons}

Longevity expectations may also play an role in determining health insurance choices, though the net effect of a higher longevity expectation on investment in health is theoretically ambiguous. Those who expect to live longer may want to spend more now on their health as such investment will pay dividends over a longer horizon (see Khwaja 2005). Thus, they would demand more insurance. On the other hand, the marginal value of additional current health investment may be lower when a long life already seems likely. The HRS collects detailed information about longevity expectations. Our focus is on the response to the question, asked of all respondents age 65 and younger, and repeated in every HRS wave, "What is (percent chance) you will live to 75 or more?" In our analysis, we use the most recent available response to this question as our measure of longevity expectations 33

Like expectations for longevity, the length of financial planning horizons (which presumably reflects both uncertainty and the subjective rate of time discount) may influence insurance choices. Here, the effect seems unambiguous, as those with longer horizons would be more willing to pay larger immediate costs (premiums) to avoid expected future costs. The HRS also collects information on financial planning horizons. Specifically, respondents in Wave 1 were asked 34

"In deciding how much of their (family) income to spend or save, people are likely to think about different financial planning periods. In planning your (family's) saving and spending, which of the time periods listed in the booklet is most important to you [and your (husband/wife/ partner)]? 1. Next few months, 2. Next year, 3. Next few years, 4. Next 5-10 years, 5. Longer than 10 years."

We use indicator variables for each of these four responses in Wave 1 as our measures of the

\footnotetext{
${ }^{33}$ This question presumably measures longevity expectations with error, and may reflect both beliefs about longevity and the degree of certainty about those beliefs. Evidence consistent with both error and uncertainty about beliefs is found in the heaping of responses around focal response such as zero, fifty and, to a lesser extent, one hundred. See Kezdi and Willis (2005) for a thorough discussion of these measures.

${ }^{34}$ This question was also asked, at random, of one out of ten respondents in Waves 4 and 5, but was not asked of anyone age 65 and older in Wave 6 . Of the 11,626 respondents who answered this question in Wave 1 , just 821 answered it again in Wave 4 and 941 in Wave 5.
} 
respondent's financial planning horizon.

\subsubsection{Measures of Cognition}

Our measure of a person's cognition combines his/her performance on four different tests/questions: word recall, a Telephone Interview for Cognitive Status (TICS) score, subtraction, and numeracy. These scores may proxy for an individual's degree of economic "rationality," i.e. his/her ability to think through the costs and benefits of Medigap insurance. There is a large body of literature showing that many of the elderly have difficulty understanding the basic Medicare entitlement, and/or the features of supplemental insurance (see, e.g., Harris and Keane 1999 for empirical evidence and Keane 2004 for a survey of the literature, much of which we cited in the introduction).

\subsection{Medigap Insurance Status}

Both the MCBS and HRS contain detailed information about respondents' health insurance choices. Specifically, each reports if the respondent is covered by Medicare, Parts A and B, and whether that coverage is provided by a Medicare Advantage Plan (HMO/PPO). We also know if the respondent had supplemental coverage and, if so, its premium and its source. Given that our goal is study the decision to buy supplemental insurance, our sample should include only people with the following characteristics: (1) they should be covered by basic Medicare (parts A and B), (2) they should not have access to free (or heavily subsidized) supplemental coverage provided by a former employer, or Medicaid, or some other government agency (e.g., the Veterans Administration). That is, we want to limit the sample to people who would have to pay more than a nominal premium to obtain supplemental coverage.

Our main empirical analysis is based on two alternative rules for sample inclusion and two alternative indicators for Medigap status. Both samples include only respondents covered by basic Medicare. In the first sample, we delete anyone covered by employer-provided supplemental health insurance, Medicaid or other government insurance (e.g., VA insurance). Then, we define Medigap status as equal to one if the respondent has purchased additional private insurance that is secondary to Medicare.

The second sample retains respondents who have employer provided supplemental insurance, provided they must pay at least $\$ 500$ per year in premiums for that insurance. Then, we again define Medigap status as equal to one if the respondent has purchased private insurance that is secondary to Medicare, but this time including the employer provided insurance for which they pay at least $\$ 500$ in premiums. 
Below, we separately report results using both definitions of Medigap status. To preview, none of the results, either qualitatively or quantitatively, depends on which definition of Medigap status we use. For our main analysis, we choose to code Medicare HMO enrollees as simply having basic Medicare because, as we mentioned earlier, 60 percent of Medicare HMO enrollees do not pay any extra premium. Thus their decision to enroll in a Medicare HMO is often really a trade-off between restrictions on provider choice vs. additional coverage for the gaps in Medicare, not a decision to pay for additional coverage. However in Section 8 we also report results where we code Medicare HMO plan members in different ways. The qualitative results do not depend on whether we treat Medicare HMO members as having "Medigap," or instead drop them from the analysis.

\subsection{Measures of Health and Medical Expenditure Risk}

Both the MCBS and HRS have detailed measures of observable health 35 For our empirical analysis, however, we need to summarize those health variables into a uni-dimensional measure of health expenditure risk. That is, while we consider extension of classic models of adverse selection to include multi-dimensional private information, we continue within the classical tradition of viewing both health risk and the level of insurance coverage as one-dimensional constructs 36

For our measure of ex post health expenditure risk, we use "Total Medical Expenditure," which corresponds to the variable pamttot in the MCBS. This variable is constructed by CMS from a variety of sources, including Medicare administrative records and survey responses ${ }^{37}$ In calculating pamttot, CMS includes, for any health care event identified either from the survey respondent or from the respondent's Medicare file, payments from 11 potential sources: Medicare fee-for-service, Medicare HMOs, Medicaid, employer-based private health insurance, individually purchased private

\footnotetext{
${ }^{35}$ See the category "Health" in the data appendix for details.

${ }^{36}$ By doing this we abstract from the following sort of possibility: suppose a person is relatively healthy overall, but chooses a Medigap plan because it has good coverage of expenses of treating a particular chronic condition from which he/she suffers. If such cases were common, it might appear that Medigap participants had lower than average total medical costs - advantageous selection - when in fact they are buying Medigap to cover costs of particular conditions. This scenario seems implausible for two reasons: First, why would people with certain chronic conditions tend to be healthier than the average person in the population in other ways? Second, it is ruled out by the legal restrictions on what Medigap plans must cover. That is, as we discussed earlier, by law Medigap plans must cover various co-pays and deductibles not covered by basic Medicare, so they can reasonably be thought of as simply providing "more" coverage in a uni-dimensional level of coverage framework. Medigap plans cannot be structured to cover or include particular health conditions.

${ }^{37}$ See MCBS public use documentation on "Cost and Use" Sections 3 and 5 for more details. This documentation is available online at http://www.cms.hhs.gov/apps/mcbs/.
} 
health insurance, private insurance managed care, private insurance with unknown sources, the VA and other public insurance, out-of-pocket payments and uncollected liability. Thus, the variable pamttot comes as close as is possible to measuring total health expenditure from all sources.

An important question is whether total medical expenditure is indeed the most relevant measure of health expenditure risk when a would-be-insured contemplates whether to purchase Medigap. One argument in favor of treating total medical expenditure as the relevant risk is that Medigap policies by law cover broad ranges of expenditure not covered by Medicare (i.e., medicare deductibles and co-pays, prescription drugs). A person in worse health would typically tend to have greater expenditure risk in all of these areas. Thus, to a good approximation, Medigap plans can reasonably be thought of a simply providing "more" coverage in a uni-dimensional health risk framework.

On the other hand, a more accurate measure of the incentive to purchase Medigap would be expected Medigap covered expenditure. Ideally if we could identify all itemized charges an individual experienced in a year, we could determine the amount of reimbursement that he/she would receive under basic Medicare vs. under various Medigap plans. Two limitations of our data preclude this approach. First, we do not have itemized medical bills; second, almost all health questions in both data sets cover health stocks, i.e., whether an individual has ever had certain treatments or diagnoses. Nonetheless, we also report results from an alternative measure of health, which is we call "Potential Medigap Expenditure." This is "Total Medical Expenditure" minus that part which is reimbursed by Medicare and other government insurance (see Section 8.1.1). This should reasonably approximate the medical expenditure that could have been covered by Medigap.

\section{Evidence of Advantageous Selection}

In this section we present a set of simple regressions that together provide strong evidence of advantageous selection in the Medigap market. Those who purchase Medigap appear to be healthier, and to have lower ex post medical expenditure. We also present direct evidence that healthier people are more likely to purchase Medigap insurance, conditional on observables that determine price.

\subsection{Descriptive Statistics}

Table 1 provides some descriptive statistics for the "Medigap" and "No Medigap" samples used in our analysis, for the MCBS and HRS separately. Recall that under our first Medigap definition we exclude from the sample those with employer provided supplemental insurance, while under 
the second definition we retain those with employer provided Medigap coverage, provided they pay a premium of at least $\$ 500$. Thus, as we move from the first to the second Medigap definition, we increase the number of observations with "Medigap," but do not change the sample with "No Medigap." Hence, the descriptive statistics for the "No Medigap" sample do not change.

There are no significant differences between the "Medigap" and "No Medigap" samples in gender and age, but they do differ significantly in their educational attainment and marital status. The mean "Total Medical Expenditure" for the "No Medigap" sample is more than $\$ 12,000$, while it is only about $\$ 8,400$ for the "Medigap" sample. On the other hand, the medical expenditure reimbursed by the Medicare is slightly higher for those with "Medigap" than for those without, consistent with the findings in the literature (see, e.g., Khandker and McCormack 1999) ${ }^{38}$

\section{[TABles 1-2 About Here]}

Under either "Medigap" definition some observations are dropped from our analysis: those covered by Medicaid or VA benefits are dropped under both definitions, and some respondents with employer sponsored insurance are dropped in each case. Table 2 provides some summary statistics on the observations that we drop. For instance, as expected, the Medicaid population is younger, but sicker. Their average medical expenditure is much higher than for people in our sample.

\subsection{Basic Regression Results: Indirect Evidence of Advantageous Selection}

Table 3 reports results from regressing "Total Medical Expenditure" on Medigap status, along with controls for the determinants of price: gender, a third-order polynomial of age, and controls for State and year 39 Panels A and B of Table 3 differ only in their definitions of "Medigap" as explained in Section 5.3. For now we focus on the results reported in columns (1)-(3), which give results for the full sample, and for male and female sub-samples 40 The column labelled "All" in each panel shows that those with Medigap have expenditures that are, on average, about $\$ 4,000$

\footnotetext{
${ }^{38}$ The view in the literature is that Medigap, by covering Medicare co-pays and deductibles, increases demand for Medicare covered services.

${ }^{39}$ Recall that, due to the government regulation of Medigap pricing, premiums depend almost exclusively on State of residence, age and gender (see Robst 2001). Of course, to the extent that gender and age predict health, the regressions also partly control for health. Total medical expenditure is higher for older individuals, as expected.

${ }^{40}$ We discuss the role of results in columns (4)-(6), that include additional demographic controls, later in Section 6.4
} 
less than those without Medigap. The negative relationship between Medigap coverage and total medical expenditure is stronger for women (about $\$ 6,000$ ) than for men (about $\$ 2,000$ ) 41

\section{[TABle 3 and 4 About Here]}

Table 4 reports results from regressions analogous to those in Table 3, but with the addition of extensive controls for health, which we describe in detail in the Data Appendix. Again we focus on results in columns (1)-(3). Conditional on observable health, those with Medigap have total health care spending of $\$ 1,900$ more, on average, than those without Medigap. The positive association between Medigap and total medical expenditure seems to be stronger for males (about $\$ 2,300$ ) than for females (about $\$ 1,500$ ).

Together, the results in Tables 3 and 4 show there is advantageous selection in the Medigap market - i.e., those with better health are more likely to purchase Medigap, and therefore Medigap enrollees have lower ex post health care expenditures than those who have only basic Medicare. Once we condition on health status, those with Medigap have higher total health expenditures, as we would expect given they face a lower price of health care 42

\section{[TABle 5 ABout Here]}

Table 5 reports results from regressions analogous to those in Table 4, except that our extensive list of health variables is summarized by five health factors using factor analysis. By examining the factor loadings (not reported), we can give interpretations to these factors ${ }^{43}$ Factor 1 can

\footnotetext{
${ }^{41}$ It is interesting that advantageous selection appears to be quantitatively larger among females. Reporting results separately for males and females is important in the light of the critiques raised by Dionne, Gouriéroux and Vanasse (2001) in their analysis of Puelz and Snow (1994). They argued that Puelz and Snow's finding of adverse selection in the automobile insurance market resulted from use of overly simple functional forms in their estimating equation, and once additional interaction terms were included, the finding of adverse selection disappears (this point was also raised in Chiappori and Salanié 2000). Reporting results separately for male and female samples is equivalent to interacting all the terms in the regression with gender. Sample size limitations prevent us from including a full set of interactions with State and age dummies as well. Later, in Section 8.1.4, we do interact the Medigap coefficient with a low order polynomial in age.

${ }^{42} \mathrm{~A}$ possible concern is that the health measures we use Table 4 could be affected by Medigap insurance status itself. For example, if those with Medigap are more likely to seek care, they may be more likely to have certain conditions diagnosed. This would make the Medigap population seem less healthy than they actually are (relative to the basic Medicare population). This would bias the Medigap coefficient in Table 4 in a negative direction (that is, we would understate the degree of advantageous selection, and understate the positive price effect).

${ }^{43}$ The factor loadings are available from the authors upon request.
} 
be interpreted as a "non-response" factor, which loads heavily on variables that are indicators of non-response (i.e., there is a non-responder type). Factor 2 loads negatively on self-reported health and positively on difficulties in instrumental activities of daily living (IADLs), and thus is an unhealthy factor. Factor 3 loads positively on self-reported health and negatively on measured medical conditions in the past two years, and thus is a healthy factor. Factor 4 loads positively on self reported health and self-reported health changes in the last year. It represents a part of self-reported health not captured by Factor 2 and 3. Factor 5 appears to be more or less noise.

The coefficient estimates for Medigap in Table 5 are qualitatively unchanged from those in Table 4. As expected, factor 2 is positively related to health care expenditure, factors 3 and 4 are negatively related, and factors 1 and 5 are not related.

\subsection{More Direct Evidence of Advantageous Selection}

The pattern of coefficients on Medigap in Tables 3-5 imply that those who purchase Medigap are healthier than those who do not. Table 6 reports more direct evidence on the same point. There, we report partial correlations between Medigap coverage and the health factors, conditional on gender and age. As before, Panels A and B present results under the two alternative definitions of Medigap. The columns labelled "EXP" simply report the regression coefficients for the factors from specification (1) in Table 5. These coefficient estimates inform us whether the factor is "healthy" or "unhealthy." The columns labelled "PCORR" report the partial correlations.

For most part, Table 6 reveals a consistent pattern: important unhealthy (healthy) factors tend to have negative (positive) and significant partial correlations with Medigap coverage. For example, in Panel A, Column "All" shows that factors 2 and 3 are the most important unhealthy and healthy factors, respectively. Factor 2, the most important unhealthy factor, has a sizeable negative correlation with Medigap (-.1166 under the first Medigap definition and -.1107 under the second) and $p$-values of almost 0 . In contrast, factor 3 , the most important healthy factor, has a positive correlation with Medigap (.0319 and .0297 respectively for the first and second Medigap definitions) and, again, $p$-values of almost 0 . The factors that have Medigap correlations of the "wrong" sign are typically of two kinds: either the factor itself is not very important (with small and insignificant coefficient estimates), or the partial correlation is statistically insignificant. The partial correlations between factors 2 and 3 and Medigap status in the male and female sub-samples are of the same signs as and similar magnitude to those for the whole sample 44

\footnotetext{
${ }^{44}$ The health factors for the three samples "All", "Female" and "Male" are separately estimated and, as a result, the factors for the three samples are actually different factors.
} 


\section{[Table 6 About Here]}

\subsection{Discussion}

So far we have established that, in the MCBS data, total expenditures for those with Medigap are, on average, about $\$ 4,000$ less than for those without Medigap, controlling only for determinants of price. But, if we also control for observable health variables, expenditures for those with Medigap average about $\$ 2,000$ more than for those without. We conclude that those with less health risk are more likely to purchase Medigap, and thus that there is "advantageous selection" in this market. Advantageous selection seems to be somewhat larger for the female population than for the male population, but in both sub-populations it is very significant, both in magnitude and statistically.

One may naturally ask whether we can find (unpriced) variables within the MCBS that both (i) affect Medigap purchase and (ii) are correlated with health. Such variables may serve as the source of advantageous selection we documented above. The demographic variables in the MCBS are the natural candidates to examine. Thus, we re-estimate the regression specifications as reported in columns (1)-(3) of Tables 3-5 with a rather complete set of demographic variables such as income, education and marital status etc., and report the results in columns (4)-(6). It is important to emphasize that, in order to establish the existence of advantageous selection, we should not include these additional demographic variables, because insurance companies are not allowed to price on them. The only reason to examine results using these additional demographic controls is to gauge the extent to which observed advantageous selection can be explained by these demographics. That is, to look for the sources of advantageous selection.

In Table 3, controlling for the additional demographics lowers the magnitude of the Medigap coefficient only slightly. For example, for the whole sample, expenditures for those with Medigap are about $\$ 3,800$ less than for those without Medigap, compared to $\$ 4,400$ without the demographic controls. But none of the qualitative results are affected by the inclusion of these controls. Similarly, in Table 4 for the whole sample, the Medigap coefficient estimate falls only slightly to $\$ 1,700$ with the additional demographic controls, compared to $\$ 1967$ without 45 In Table 5 when we use health factors, again the point estimate of Medigap changes only modestly when we add the demographic controls.

Thus we conclude that the bulk of advantageous selection is left unexplained by demographics

\footnotetext{
${ }^{45}$ In regressions reported in specifications (4)-(6), we find that total medical expenditure is higher for individuals with annual income above $\$ 45,000$; but education does not seem to have a systematic effect on total medical expenditure.
} 
such as race/ethnicity, income, education and marital status. As a result, we will have to extend our search for the sources of advantageous selection, which we describe in detail in the section below.

\section{Sources of Advantageous Selection}

In Section 6, we used MCBS data to provide both direct and indirect evidence of quantitatively important advantageous selection - healthier seniors with lower ex post expenditure risk are more likely to purchase Medigap. In this section we investigate the sources of advantageous selection. That is, we seek to identify dimensions of individuals' private information that satisfy the two properties we mentioned in Section 3: i.e., unpriced variables that both (i) make individuals more likely to purchase Medigap, and (ii) are negatively correlated with their health expenditure risk.

\subsection{Empirical Strategy}

The ideal data set for our analysis would be the HRS augmented by links to Medicare administrative data containing information on total medical expenditure. Unfortunately HRS is not yet properly linked to the Medicare administrative records, and has poor information on out-of-pocket spending relative to MCBS. On the other hand, MCBS does not contain information about many suspected sources of advantageous selection. We now describe our empirical strategy that combines MCBS and HRS to examine the sources of advantageous selection 46

The data in MCBS can be written as

$$
\left\{E_{i}, M_{i}, \mathbf{H}_{i}, \mathbf{D}_{i}\right\}_{i \in \mathcal{I}_{M C B S}},
$$

and the data in HRS as

$$
\left\{M_{j}, \mathbf{H}_{j}, \mathbf{D}_{j}, \mathbf{X}_{j}\right\}_{j \in \mathcal{I}_{H R S}}
$$

where $\mathcal{I}_{M C B S}$ and $\mathcal{I}_{H R S}$ denote the MCBS and HRS sample respectively. Note that the variables $\{M, \mathbf{H}, \mathbf{D}\}$, which denote Medigap coverage, health measures and demographics, are common to both data sets. But $E$, total medical expenditure, appears only in the MCBS, while $\mathbf{X}$, the list of variables that we think are potential sources of advantageous selection, appears only in the HRS.

\footnotetext{
${ }^{46}$ There is a sizeable literature on empirical methods to deal with the incomplete data by combining multiple data sets. See, for example, Angrist and Krueger (1992), Arellano and Meghir (1992), Ichimura and Martinez-Sanchis (2004) and references therein. But none of the methods developed in these papers applies to our problem.
} 
Our empirical strategy uses the MCBS data to estimate prediction equations for total medical expenditure risk, as well as its variance. These equations will utilize covariates that are also available in the HRS, so that we can use the prediction equations to impute the mean and variance of ex post health expenditures for each person in our HRS sample. Implementation of this strategy requires a determination about which sample in MCBS to use in estimating the prediction equations. Conceptually, we want a measure of expenditure risk for a person in the position of having only basic Medicare who is considering whether to buy Medigap. To do this, should we use only those without Medigap, or should we use the whole sample? We follow a practical strategy and estimate the prediction equations in both ways. Then we show that our results are robust to which sample we use.

Prediction Equations Using MCBS Subsample with No Medigap Coverage. In the first method, we only use the subsample in MCBS with no Medigap coverage to estimate the mean and variance of medical expenditures. Suppose the mean and variance prediction equations obtained from the MCBS are:

$$
\begin{aligned}
\hat{E}_{i 1} & =\hat{\alpha}_{0}+\hat{\boldsymbol{\alpha}}_{1} \mathbf{H}_{i}+\hat{\boldsymbol{\alpha}}_{2} \mathbf{D}_{i}, \\
\widehat{V A R_{i 1}} & =\left(E_{i}-\hat{E}_{i 1}\right)^{2}=\hat{\beta}_{0}+\hat{\boldsymbol{\beta}}_{1} \mathbf{H}_{i}+\hat{\boldsymbol{\beta}}_{2} \mathbf{D}_{i} .
\end{aligned}
$$

We can then impute the mean and variance of medical expenditures for the HRS sample as follows: for each $j \in \mathcal{I}_{H R S}$, the imputed mean medical expenditure is

$$
\hat{E}_{j 1}=\hat{\alpha}_{0}+\hat{\boldsymbol{\alpha}}_{1} \mathbf{H}_{j}+\hat{\boldsymbol{\alpha}}_{2} \mathbf{D}_{j}
$$

and the imputed variance of medical expenditure is

$$
\widehat{V A R}_{j 1}=\hat{\beta}_{0}+\hat{\boldsymbol{\beta}}_{1} \mathbf{H}_{j}+\hat{\boldsymbol{\beta}}_{2} \mathbf{D}_{j}
$$

Prediction Equations Using the Whole MCBS In the second method, we use the whole MCBS sample to estimate the mean and variance of medical expenditure. In this case, we include in the regressions a Medigap status indicator $M_{i}$. That is,

$$
\begin{aligned}
\hat{E}_{i 2} & =\hat{\gamma}_{0}+\hat{\gamma}_{1} M_{i}+\hat{\gamma}_{2} \mathbf{H}_{i}+\hat{\gamma}_{3} \mathbf{D}_{i} \\
\widehat{V A R_{i 2}} & =\left(E_{i}-\hat{E}_{i 2}\right)^{2}=\hat{\xi}_{0}+\hat{\xi}_{1} M_{i}+\hat{\boldsymbol{\xi}}_{2} \mathbf{H}_{i}+\hat{\boldsymbol{\xi}}_{3} \mathbf{D}_{i}
\end{aligned}
$$

We then impute the mean and variance for each member $j \in \mathcal{I}_{H R S}$ of the HRS sample, as follows:

$$
\begin{aligned}
\hat{E}_{j 2} & =\hat{\gamma}_{0}+\hat{\gamma}_{2} \mathbf{H}_{j}+\hat{\gamma}_{3} \mathbf{D}_{j} \\
\widehat{V A R_{j 2}} & =\hat{\xi}_{0}+\hat{\boldsymbol{\xi}}_{2} \mathbf{H}_{j}+\hat{\boldsymbol{\xi}}_{3} \mathbf{D}_{j}
\end{aligned}
$$


Note that in the imputation equations (13) and (14), we set $M_{j}$ equal to zero for the HRS sample. Thus the predictions above are for the mean and variance of medical expenditures for a person without Medigap coverage.

Pros and Cons of the Two Imputations. Conceptually, neither of the above imputation methods is perfect. If selection into Medigap were random, then either approach would be correct. However, given selection, each method has a limitation. First, $\hat{E}_{j 1}$ may not be an unbiased estimate of pre-Medigap-purchase mean health expenditure risk. For example, if those with Medigap have systematically better unobserved health (just as they have better observed health), then $\hat{E}_{j 1}$ will tend to over-estimate expected medical expenditure for those in HRS who actually have Medigap. This will lead us to understate the degree of advantageous selection in the HRS.

In the second imputation method it is necessary to include the Medigap status indicator $M_{i}$ in prediction equations (11) and (12). Otherwise we will exaggerate the pre-Medigap-purchase expenditure risk by including in it the positive "moral hazard" or price effect of Medigap coverage. However, given selection into Medigap, the Medigap coefficient will be biased. For example, if those with Medigap have systematically better unobserved health (just as they have better observed health), the Medigap coefficient will be downward biased (i.e., we understate the price effect). This would cause $\hat{E}_{j 2}$ to also overstate the pre-Medigap expenditure risk for those who actually have Medigap.

Despite these conceptual problems, it is worth emphasizing that the list of observable health variables that we include in our imputation is extremely detailed and captures a broad range of conditions. Thus, it is plausible that selection based on unobserved health may not be quantitatively important. The fact that the qualitative results below are robust to either of the above imputation methods also lends credibility to our findings.

Identifying the Sources of Advantageous Selection. Next we describe our approach to identifying the sources of advantageous selection. With the imputed $\hat{E}_{j k}$ and $\widehat{V A R_{j k}}$, our augmented HRS data can now be represented as:

$$
\left\{M_{j}, \mathbf{H}_{j}, \mathbf{D}_{j}, \mathbf{X}_{j}, \hat{E}_{j k}, \widehat{V A R_{j k}}\right\}_{j \in \mathcal{I}_{H R S}}
$$

For simplicity, we henceforth suppress the subscript $k$ that denotes the method of imputation but report results separately for $k \in\{1,2\}$.We first regress

$$
M_{j}=\delta_{0}+\delta_{1} \hat{E}_{j}+\boldsymbol{\delta}_{2} \mathbf{D}_{j}+\varepsilon_{j},
$$


where, as before, the variables in $\mathbf{D}_{j}$ include a third order polynomial in age, gender and State of residence, to capture the pricing of Medigap insurance. As we report below, and consistent with our finding in Section 6 , we obtain a negative and significant estimate for $\delta_{1}$, implying advantageous selection in the purchase of Medigap in the HRS.

Next, in order to determine the sources of advantageous selection, we gradually add controls from the list of variables contained in $\left\{\mathbf{X}_{j}, \widehat{V A R}\right\}$. We first sequentially add risk tolerance risktol $_{j}$, and the interaction between risk tolerance risktol $_{j}$ and expenditure risk measure $\widehat{V A R_{j}}$. Then we add other potential sources of advantageous selection, including education, income, cognition, longevity expectation and financial planning horizon, in that order.

As we show below, when we estimate the partial correlation between Medigap coverage and health expenditure risk, controlling not only for the determinants of price, $\mathbf{D}_{j}$, but also for $\left\{\mathbf{X}_{j}\right.$, $\widehat{V A R}\}$, the partial correlation will turn positive. More precisely, when we estimate

$$
M_{j}=\theta_{0}+\theta_{1} \hat{E}_{j}+\theta_{2} \text { risktol }_{j}+\theta_{3} \widehat{V A R}_{j} \times \text { risktol }_{j}+\boldsymbol{\theta}_{4} \mathbf{X}_{j}+\boldsymbol{\theta}_{5} \mathbf{D}_{j}+\varepsilon_{j}
$$

we find that $\hat{\theta}_{1}$ is positive and significant - consistent with the "positive correlation property" predicted by standard insurance models with uni-dimensional private information. This is the sense in which we say we have successfully identified several key sources of advantageous selection.

Comments About Our Empirical Strategy. Three comments about our approach are worth stressing. First, the imputation of expected medical expenditure levels for each member of the HRS (based on a prediction equation estimated using the MCBS) is meant to summarize a person's overall health risk type in a single variable. We need to enter a single uni-dimensional "risk" measure into regression equation (16) in order to test the positive correlation property. An alternative strategy would be to use the extensive set of health measures available in the HRS, $\mathbf{H}_{j}$, to construct a single measure of a person's health. But this approach is not feasible for two reasons: (1) When we factor analyze the health variables we obtain three independent and important health factors (see Section 6.2). Thus, the health measures do not provide us with a uni-dimensional measure of health risk. (2) From a theoretical point of view, for purposes of judging selection into different types of insurance coverage, the relevant variable is expenditure risk, not health status per se (e.g., a person could be less healthy but also less expensive to treat, or even untreatable).

Second, an alternative (and in some sense symmetric) empirical strategy would be to impute the missing variables in the list $\mathbf{X}$ for the MCBS sample, using prediction equations for $\mathbf{X}$ from the HRS sample. However, it is not clear what variables in the HRS could be used to predict $\mathbf{X}$ except 
for the demographic variables. Moreover, this approach would require imputation of several more variables than our approach.

Finally, the limitations of all the imputation methods we have described would suggest estimation of a joint model of Medigap purchase and health expenditures, with explicit modelling of selection, using data from the MCBS and HRS simultaneously. This is an important direction for future research, but it would involve much stronger assumptions about the joint distribution of $\left\{M_{j}, E, \mathbf{H}_{j}, \mathbf{D}_{j}, \mathbf{X}_{j}\right\}$.

\subsection{Comparison of MCBS and HRS Data}

Before we describe our main results, we first show that the MCBS and HRS samples are in fact quite similar, suggesting that using the MCBS to impute means and variances of medical expenditure for the HRS is reasonable. Panel A of Table 7 compares MCBS and HRS means for the common set of demographic variables, using the sample based on the first definition of Medigap. The fraction female and conditional age distributions are roughly similar. The percentage of individuals with Medigap is also similar in the two samples: 45.9 percent in the MCBS and 48.6 percent in the HRS ${ }^{47}$ In both the MCBS and HRS, close to 95 percent of the sample are covered by both Medicare A and B. Marital status, number of children and educational attainment differ only slightly in the two surveys.

[TABle 7 About Here]

Panel B of Table 7 reports similar comparisons between the MCBS and HRS for the sample based on the second definition of Medigap. As expected, adding those with employer sponsored health insurance slightly lowers the female proportion, because more of those still working (or retired from employers who provide retiree health benefits) are men, and slightly lowers the average age, because those still working tend to be slightly younger. The percentage with Medigap increases to 54.5 percent in MCBS and 56.8 percent in HRS. Overall, the MCBS and HRS samples appear to be quite similar in the means of the common set of demographic variables.

\subsection{Sources of Advantageous Selection: Main Findings}

This section reports our main results regarding the sources of advantageous selection. Table 8 reports results based on our first method of imputing health expenditure risk (see Section 7.1).

\footnotetext{
${ }^{47}$ Medicare HMO enrollees are treated as having only basic Medicare in these summary statistics.
} 
Panel A and B respectively report the results for the two definitions of "Medigap" insurance status (see Section 5.3 for details). In the first three columns of each panel we report estimates of the coefficient on predicted health expenditure $\hat{E}_{j}$ in equations $(16)-(17)$. We actually enter $\hat{E}_{j}$ into the regressions in tens of thousands of dollars $(\$ 10,000)$ to make the results more easily interpretable. The next several columns labelled "Conditioning Variables" indicate the list of control variables included in $X$, with "Y" ("N") indicating that a particular variable is (is not) included. The last column gives the sample size for the regression.

Notice that, as we add more variables to the regressions, the number of observations drops, due to missing values ${ }^{48}$ Two variables lead to substantial loss of observations: First, adding risk tolerance to the regression eliminates about $2 / 3$ of the sample, because the HRS only asked these questions in about a one-third sub-sample. Second, when we include the cognition variables (in particular cognition questions related to numeracy) we lose another half of the sample. In order to avoid the possibility that our results are driven by the changing samples, we re-run all our regressions on three samples. Column A reports results using the full sample, column B reports results for medium sample (for which the risk tolerance measure is available), and column $\mathrm{C}$ for the smallest sample (for which the cognition variables are available).

Rows (1) and (9) show that, regardless of the definition of "Medigap" insurance status, if we do not control for any of the $X_{j}$ variables, individuals with higher health expenditure risk are less likely to purchase Medigap. For the sample with the most complete data, the point estimates imply that a $\$ 10,000$ increase in health expenditure risk reduces the probability of buying Medigap by 5.7 to 7.6 percentage points. This, of course, is simply a confirmation (from a different angle and using different data) of our finding of advantageous selection reported in Section 6 .

Rows (2) and (10) add risk tolerance alone to the regression (16). This specification is important because the previous literature we have cited, both theoretical and empirical, has focused almost exclusively on risk aversion as the source of advantageous selection. Note that the inclusion of risk tolerance only slightly reduces, if at all, the magnitude of the negative coefficient on predicted health expenditures. This result does not depend on the linear specification for the effect of risk tolerance. If, instead, risk tolerance enters as third-order polynomial or as a complete set of dummy variables, the point estimate of coefficient on $\hat{E}_{j}$ is essentially unchanged. Risk tolerance is, however, a significant predictor of Medigap purchase. When entered as a set of dummy variables, an $F$-test rejects the null hypothesis of joint insignificance with a $p$-value of less than 0.001 .

Results do change, however, when we also control for the variance of health expenditures. In

\footnotetext{
${ }^{48}$ Most of the missing values result from the relevant survey questions not being asked, instead of non-response.
} 
rows (3) and (11) we report results from a regression that includes risk tolerance, the predicted variance, and the interaction between the two. The inclusion of these measures affects the coefficient estimate on $\hat{E}_{j} \sqrt{49}$ In the medium samples, the estimated coefficient on $\hat{E}_{j}$ remains negative, but is now statistically indistinguishable from zero. In the small samples, the coefficient on $\hat{E}_{j}$ reverses its sign from negative to positive, though it is statistically indistinguishable from zero.

Notably, the estimated coefficient on the level of risk tolerance and the interaction between variance $\widehat{V A R}_{j}$ and risk tolerance are both negative. The latter is as we would expect. Thus, the probably of buying insurance increases with greater risk aversion, and more so for a person who faces a higher variance of expenditures. According our point estimates, at the mean level of $\widehat{V A R}_{j}$ in our sample, a one standard deviation increase in the risk tolerance measure decreases the probability of purchasing Medigap by 6.7 percentage points. It is also interesting to note that the coefficient on the variance term $\widehat{V A R}_{j}$ is negative. As the interaction between variance and risk tolerance is also negative, this implies that individuals with higher uncertainty in their medical expenditures are less likely to purchase Medigap (with this negative effect being larger for people who are more risk tolerant).

As we include more variables from $\mathbf{X}_{j}$, reported in rows (4)-(8) for the first Medigap definition and in rows (12)-(16) for the second Medigap definition, the coefficient on $\hat{E}_{j}$ eventually becomes positive and statistically significant at the 5 to 10 percent level. The most complete specification implies that a $\$ 10,000$ increase in predicted health expenditure increases the probability of buying Medigap by 7.8 percentage points. All of the new $\mathbf{X}_{j}$ variables we include shift the partial correlation between health expenditure risk and Medigap coverage in a positive direction.

Among all the variables in $\mathbf{X}_{j}$, cognition and income are distinctive. If only cognition and/or income are included in $\mathbf{X}_{j}$, it substantially changes the estimated coefficient on $\hat{E}_{j}$; and when all variables in $\mathbf{X}_{j}$ are included in the regression, both cognition and income stand out as significant predictors of Medigap purchase 50

For example, adding the cognition variables alone changes the coefficient on $\hat{E}_{j}$ from -.057, $p$-value 0.12 , to -.012, $p$-value 0.68 ; and in the full regression that includes all elements of $\mathbf{X}_{j}$, a standard deviation increase in just the TICS score is associated with a 5.4 percentage point increase in the probability of purchasing a Medigap policy. Similarly, adding income variables alone changes

\footnotetext{
${ }^{49}$ The bulk of the change in the coefficient on $\hat{E}_{j}$ is attributable to the inclusion of a control for the variance in health expenditure. For example, in results not shown here, adding just a control for variance in the smallest sample increases the coefficient on $\hat{E}_{j}$ to $.0370, p$-value .143 , when we use the first definition of Medigap.

${ }^{50}$ For reasons of space, these results are not presented here but are available from the authors upon request.
} 
the coefficient on $\hat{E}_{j}$ from -.057, $p$-value 0.12 , to -.022, $p$-value 0.45 ; and someone with an annual income between 45 and 50 thousand dollars is 12 percentage points more likely to purchase a Medigap Policy than is someone with an income between 15 to 20 thousand dollars. Thus, both cognition and income provide some important part of the explanation for the otherwise negative correlation between mean expenditure risk and insurance purchase.

It is worth noting that while most of the elements of $\mathbf{X}_{j}$ would be standard elements of any complete economic model of insurance choice, cognition is unusual. As discussed in Section 5.2.3, the cognition variable may proxy for an individual's degree of economic "rationality," i.e. his/her ability to think through the costs and benefits of Medigap insurance ${ }^{51}$ It's significance is consistent with a large literature suggesting many senior citizens have difficulty understanding the rules of the Medicare program and the features of Medigap policies (see the introduction for further discussion and citations).

\section{[TABles 8-9 About Here]}

Table 9 reports analogous results using the second imputation method we described earlier, where we use all observations in the MCBS to estimate the prediction equations (11) and (12). The results in Table 9 are qualitatively very similar to those in Table 8 . Note, however, that the results in Panel B of Table 9, where we use the second definition of Medigap status, are somewhat weaker in terms of statistical significance.

In summary, these results indicate that sources of the advantageous selection we documented in Section 6 include a number of factors - income, education, longevity expectations and financial planing horizon - that would typically enter a rich economic model of insurance purchase. In addition, however, we find evidence that factors typically omitted from economic models, such as levels of cognition and financial numeracy, are also important sources of advantageous selection. Those who are likely better able to calculate the costs and benefits of Medigap purchase are both healthier and more likely to purchase Medigap. We find no evidence, however, that risk preferences, which the theoretical literature has focused on, and which are significant predictors of Medigap purchase, can explain advantageous selection in this market. These findings are robust to changes in the sample and in the methods we use to impute expected medical expenditure and its variance.

Thus, this is, to the best of our knowledge, the first study to provide direct evidence on the sources of advantageous selection in health insurance markets; it is also the first study to identify

\footnotetext{
${ }^{51}$ One might be concerned that cognition actually proxies for a dimension of health. But it should be noted that the health control variables include extensive measures of mental and neurological illnesses including Alzheimer's disease.
} 
a set of variables that are sufficient to explain away the negative correlation between ex post health expenditure and Medigap coverage documented in Section 6, and obtain a positive partial correlation between health expenditure risk and the level insurance coverage.

\section{Robustness of Results}

In this section we describe several additional checks on the robustness of our results, using alternative measures of health risk, alternative treatments of Medicare HMO/Medicare Advantage Plan participants, trimming of outliers, and alternative measures of the degree of uncertainty in health expenditures (other than the predicted variance $\widehat{V A R}_{j}$ we used in Section 7).

\subsection{Robustness of the Evidence of Advantageous Selection}

\subsubsection{Alternative Uni-dimensional Measures of Health}

So far we have used "Total Medical Expenditure" as a uni-dimensional measure of health (see Section 5.4 for justification and discussion). Here we show that our findings about advantageous selection remain substantively unchanged if we replace this measure with the level of medical expenditure that is not reimbursed by Medicare. We call this alternative measure "Potential Medigap Expenditure" because it is arguably a good approximation of the expenditure risk faced by a person who has only basic Medicare coverage. Panel A of Table 10 examines the sensitivity of our results to using this alternative measure.

[TAble 10 About Here]

Columns (1) and (2) of Table 10 reproduce the Medigap coefficients from Tables 3-4 (based on total expenditure), while columns (3)-(4) present the results using potential Medigap expenditure. We report results from two regression specifications in the rows labelled (1) and (2). Regression (1) is the baseline specification that includes only gender, an age polynomial and State of residence as controls for price. Regression (2) adds the controls for health. As can be seen from Table 10, if we use potential Medigap expenditure as an alternative measure of health expenditure risk, the basic message of advantageous selection persists: controlling only for variables used to price Medigap, the Medigap coefficients are in the range of $-\$ 4,000$. But, when we control for health, they turn positive. The positive values are not as large when we use potential Medigap expenditure as the measure of health. But the key point is that inclusion of the observable health variables significantly 
increases the magnitude of the Medigap coefficient in either case, thus indicating, once again, that those with Medigap are healthier.

\subsubsection{Alternative Treatments of Medicare HMOs}

So far we have treated anyone with only Medicare coverage (whether it is basic Medicare fee-forservice or a Medicare HMO) as not having Medigap. However, in 2000 and 2001, approximately 15 percent of all Medicare beneficiaries chose to participate in a "Medicare Advantage Plan." These are HMOs that have contracted with Medicare to provide Medicare insurance. These plans are not available everywhere, especially not in rural areas. They require participation in Medicare A and $\mathrm{B}$, and often charge additional premiums. The benefit to participants of the extra premiums and the restrictions imposed by the HMO is that the HMO "generally" fills the same gaps that Medigap policies do. Thus, the U.S. government's "Guide to Choosing a Medigap Policy" tells those who have selected a Medicare Advantage Plan that they do not need a Medigap policy. We experimented with coding those who have chosen a Medicare HMO either as having a Medigap status $M_{i}$ of 1 or coding these respondents as missing.

Panel B of Table 10 reports the Medigap coefficient estimates for two alternative treatments of those who belong to Medicare HMOs. Columns (1) and (2) report results when they are coded as having Medigap; while in Columns (3) and (4) they are coded as missing. We note that the recoding of Medicare HMO participants actually strengthens our findings of advantageous selection in Section 6. For example, the negative coefficients of $M_{i}$ in Table 3 became even more negative. This is not surprising given the strong consensus in the literature (noted earlier) that there is advantageous selection into Medicare HMOs. Also, counting Medicare HMO participants as having Medigap does not change the qualitative findings about the sources of advantageous selection in Section 7.3 . Alternatively, dropping those observations from our analysis also does not change the results, either qualitatively or quantitatively.

\subsubsection{Trimming the Outliers}

"Total Medical Expenditure" is known to be right skewed in the population. For example, in our selected sample, "Total Medical Expenditure" has a skewness of 4.2, with a mean of $\$ 10,679$ and a median of $\$ 3,467$; the "Potential Medigap Expenditure" we used in Section 8.1.1 is less right skewed with a skewness of 3.5 , a mean of $\$ 6,040$ and a median of $\$ 2,292$. One may argue that outlier medical expenditures are the medical expenditure risks of particular concern when individuals consider whether to purchase Medigap. Nevertheless, in Panel C of Table 10 we address 
the concern that our results are driven by these outliers. Columns (1) and (2) report the Medigap coefficient estimates after we drop the observations whose "Total Medical Expenditure" is above the 95th percentile. The coefficient estimates, not surprisingly, go down, but the qualitative conclusion regarding the presence of advantageous selection is not affected. Columns (3) and (4) of Panel C report the results after we trim the top $5 \%$ of those with high "Potential Medigap Expenditure." Again, the coefficients are smaller in magnitude, but the qualitative results are the same.

\subsubsection{Accounting for Dynamic Lock-in Incentives}

As we mentioned in Section 4.2 (especially in Footnote 26), if an individual's Medigap coverage lapses, insurance companies may subsequently impose both coverage and pricing rules different from those which apply during the open enrollment period. A potential concern is that our Medigap price controls (age polynomial, gender and state of residence) do not reflect the prices faced by those who let their coverage lapse. In this case, our finding that expenditures for those with Medigap are about $\$ 4,000$ less than for those without may, to some extent, reflect the following possibility: those without Medigap are less healthy because their coverage previously lapsed and, moreover, are currently priced out of Medigap due to their poor health. We argue here, however, that if this mechanism is influencing our estimates its effect is consistent with our interpretation of advantageous selection.

Consider the group of individuals without Medigap who are unhealthy and priced out of Medigap because of a lapse in their coverage. One possibility is that they never purchased a Medigap policy in the first place. This would be consistent with our interpretation of advantageous selection: less healthy individuals are less likely to purchase Medigap during open enrollment (when everyone is approximately the same age and thus state and gender controls alone would be sufficient to control for Medigap pricing). The second possibility is that those without Medigap did purchase a policy during open enrollment, but subsequently failed to renew. The standard adverse selection model with one dimensional private information about risk suggests that less healthy people should be more likely to renew, just as they should be more likely to enroll in the first place. If, in contrast, less healthy people are less likely to renew, we would argue that this is again a form of advantageous selection.

To further investigate the influence of age-patterns on our findings, we re-estimate the regressions reported in Table 3 and 4 but allow age to interact with Medigap status (specifically we allow for the relationship between Medigap and "Total Medical Expenditure" to depend on age and its 
square and cube) 52 The estimated coefficients of Medigap as a function of age are then plotted in Figure 1. To save space we only report the results for the first Medigap status definition (the results for the second Medigap status definition are essentially identical). Figure 1 reveals that without health controls, those with Medigap had less "Total Medical Expenditure" than those with Medigap at all age levels; and with health controls, those with Medigap had more expenditure than those with Medigap, again, at all age levels. These findings suggest that age affects the magnitude but not the presence of advantageous selection in this population 53

[Figure 1 About Here]

\subsection{Robustness for the Sources of Advantageous Selection}

\subsubsection{Alternative Uni-dimensional Measures of Health}

As in the previous subsection, here we first show that the qualitative conclusions regarding the sources of advantageous selection remain unchanged if we used "Potential Medigap Expenditure," i.e., the level of medical expenditure that is not reimbursed by Medicare as an approximation of the expenditure risk faced by a person who has only basic Medicare coverage.

\section{[TABle 11 About Here]}

Panel A of Table 11 shows the results from regressions similar to those reported in Tables 8 and 9, except that we use MCBS to impute the "Potential Medigap Expenditure" instead of "Total Medical Expenditure" for the HRS sample ${ }^{54}$ Similar to what we found earlier, we see evidence of advantageous selection in row (1). However we are able to explain away the advantageous selection by the addition of the conditioning variables.

\subsubsection{Alternative Measure of Health Expenditure Risk}

In Section 7, we used the variance of medical expenditures as our measure of uncertainty in $e x$ post health expenditures. As noted in the previous subsection, one may argue that individuals care especially about catastrophically large medical expenses, and hence the second moment may not

\footnotetext{
${ }^{52}$ No demographic controls are included for the regression specification with health controls.

${ }^{53}$ Understanding the effects of age on the magnitude of advantageous selection is important and interesting topic for future research.

${ }^{54}$ To save space we only report the results for Medigap definition 1 . The results for Medigap definition 2 are qualitatively similar.
} 
be the best measure of the relevant risk. In Panel B of Table 11, we report results from regressions similar to those reported in Tables 8 and 9 (for Medigap status definition 1) with the exception that we use the predicted 90/10 percentile ratio as our measure of the health expenditure risk (instead of the predicted variance). More specifically, we use the MCBS sample, again with two different imputation methods similar to those described above, to run quantile regressions for 90th and 10th quantile respectively; and then use these quantile regression coefficients to predict $\hat{Q}_{j 90}$ and $\hat{Q}_{j 10}$ for the HRS sample; then for each observation in HRS, we construct $\hat{Q}_{j 90 / 10}=\hat{Q}_{j 90} / \hat{Q}_{j 10}$ as the measure of the medical expenditure risk, in place of $\widehat{V A R}_{j}$. From the coefficient estimates in Panel $\mathrm{B}$ of Tables 11, it is quite clear that our qualitative results regarding the sources of advantageous selection are robust to this alternative measure of health expenditure risk.

\section{Discussion: Selection versus Moral Hazard}

A challenging question of central importance in the economics of information is whether we can distinguish selection (either adverse or advantageous) from moral hazard. Chiappori and Salanié's (2000) test for asymmetric information, for example, is not designed to discriminate between adverse selection and moral hazard, since both can lead to a positive sign of the relationship between $e x$ post risk occurrence and insurance coverage 55 In this section, we briefly discuss the implications of our results in Section 6 for the issue of selection versus moral hazard. We argue that, under some conditions, the coefficient estimates on "Medigap" presented in Table 2 and 3 also provide lower bound estimates of moral hazard (or simply, the price effect) of Medigap insurance.

To see this, suppose that the true medical expenditure equation is

$$
E_{i}=\beta_{0}+\beta_{1} M_{i}+\boldsymbol{\beta}_{2} \mathbf{H}_{i}^{O}+\boldsymbol{\beta}_{3} \mathbf{D}_{i}+\beta_{4} U_{i}+\varepsilon_{i}
$$

where $E_{i}$ is total medical expenditure, $M_{i}$ is the "Medigap" indicator, $\mathbf{H}_{i}^{O}$ is the observed component of health, $\mathbf{D}_{i}$ is a list of demographic controls, and $U_{i}$ is an index of unobservables capturing both unobservable components of health and preferences for medical service. Assume that residual, $\varepsilon_{i}$, is uncorrelated with the independent variables.

In this equation $\beta_{1}$ will be the true measure of the moral hazard (or price) effect, because we

\footnotetext{
${ }^{55}$ Abbring, Chiappori and Pinquet (2003) and Abbring, Chiappori, Heckman and Pinquet (2003) propose using dynamic insurance data to discriminate between selection and moral hazard. The idea is that, in dynamic automobile insurance contracts where experience rating is an important feature, adverse selection will lead to positive, while moral hazard will lead to negative, serial correlation in accident probabilities. Thus dynamic insurance data may enable researchers to qualitatively discriminate adverse selection from moral hazard.
} 
are assuming that the observed health $\mathbf{H}^{O}$ and the unobserved $U$ jointly control for the true health and taste for medical services, thus eliminating selection issues. The problem, however, is that $U_{i}$, which contains unobserved components of health and preferences for medical service, cannot actually be included.

The regressions we reported in Tables 2 and 3 are of the form:

$$
E_{i}=\tilde{\beta}_{0}+\tilde{\beta}_{1} M_{i}+\tilde{\boldsymbol{\beta}}_{2} \mathbf{H}_{i}^{O}+\tilde{\beta}_{3} \mathbf{D}_{i}+\tilde{\varepsilon}_{i}
$$

which differs from (18) because we only control for the observable component of health $\mathbf{H}_{i}^{O}$ and not $U_{i}$. Thus, $\tilde{\beta}_{1}$ is biased as an estimator of $\beta_{1}$ because of the omission of $U_{i}$. As is well-known, the degree of omitted variable bias can be calculated if we run an auxiliary (and imaginary) regression: 56

$$
U_{i}=\pi_{0}+\pi_{1} M_{i}+\pi_{2} \mathbf{H}_{i}^{O}+\boldsymbol{\pi}_{3} \mathbf{D}_{i}+\mu_{i}
$$

Then, we have that:

$$
\tilde{\beta}_{1}=\beta_{1}+\beta_{4} \pi_{1}
$$

If, without loss of generality, we define the unobservables in $U_{i}$ to be "positives" (i.e., factors that will lead to less medical expenditure - i.e., health and distaste for treatment), we will have by definition $\beta_{4}<0$. Then, our estimate $\tilde{\beta}_{1}$ will be a lower bound of $\beta_{1}$ - and thus a lower bound estimate of the moral hazard (or price) effect - provided that $\pi_{1} \geq 0$. Note that parameter $\pi_{1}$ measures the partial correlation between $U_{i}$ and $M_{i}$ conditional on observable health $H^{O}$ and $\mathbf{D}$ (which are controls for Medigap prices). The condition $\pi_{1} \geq 0$ means that $U$ and $M$ are positively correlated conditional on $H^{O}$ and Medigap pricing.

In practice, regression (20) can never be implemented, thus it is impossible to examine whether the condition $\pi_{1} \geq 0$ is satisfied. There are, however, some plausible cases in which we may expect this condition to be true. Assume that, conditional on health and demographics, tastes for medical service are unrelated to the taste for Medigap insurance purchase. This means that the variable $U_{i}$ only contains the unobserved health component $H_{i}^{U}$. The sign of the partial correlation between $H_{i}^{U}$ and $M_{i}$ of course depends on how people select into Medigap. There are two scenarios under which $\pi_{1} \geq 0$ will be satisfied:

One interesting case is where the person knows no more about his/her health than we do. This is not unreasonable, given the that we have the person's subjective health assessment, along with the very extensive list of objective health measures in the MCBS/HRS. In that case, individuals

\footnotetext{
${ }^{56}$ See, e.g., Wooldridge (2006, p. 120) for an expression of the omitted-variable bias (although note that it contains a typo).
} 
will make Medigap purchase decisions based only on observable health $H_{i}^{O}$. Then $\pi_{1}$ will be zero, so we get a consistent estimator of the price effect.

Alternatively, suppose that $H_{i}^{U}$ (some part of it) is observed by individuals when they make Medigap purchase decisions. Then the assumption that $\pi_{1} \geq 0$ amounts to assuming that selection based on unobserved health is also advantageous. While we can never explicitly verify whether or not this is true, it seems plausible, given the strong evidence of advantageous selection based on observed health 57

Finally, consider a case where $U_{i}$ contains only distaste for treatment. This case is difficult to analyze. In a static model, those with more distaste for health care would both demand fewer services and, conditional on demographics and observed health, be less likely to buy Medigap, so we get $\pi_{1}<0$. The difficultly arises because, in a dynamic model, it is not clear how tastes for health care would translate into demand for services (e.g., a person who dislikes treatment would get less preventive care, possibly leading to more required services in the long run).

\section{Conclusion}

In this paper we use data from the Medicare Current Beneficiary Survey (MCBS) to provide strong evidence of advantageous selection in Medigap insurance market. The first type of evidence comes from two sets of regressions. In the first, we regress "Total Medical Expenditure" on Medigap status, and only control for the determinants of price (gender, age and State of residence). We find that those with Medigap incur, on average, about $\$ 4,000$ less in total medical expenditure than those without Medigap. In the second set of regressions, we regress "Total Medical Expenditure" on the determinants of price along with a rich set of controls for health status. Conditional on price and health, we find that those with Medigap incur about $\$ 2,000$ more in medical expenditures, on average, than those without Medigap. These two sets of results can only be reconciled if those with better health are more likely to purchase supplemental coverage - i.e., if there is "advantageous selection."

We also find direct evidence of advantageous selection by showing that "healthy" factors (i.e. factors constructed directly from health measures) tend to be positively correlated with Medigap coverage, while "unhealthy" factors tend to be negatively correlated with Medigap coverage. These results are robust to different definitions of Medigap status, to separating the sample into male and

\footnotetext{
${ }^{57}$ In this particular case, it is important to emphasize that whether or not the condition $\pi_{1} \geq 0$ is satisfied is not constrained by the covariance of $H_{i}^{O}$ and $H_{i}^{U}$. In other words, even in situations where $H_{i}^{U}$ and $H_{i}^{O}$ are negatively correlated (which is plausible when we think of $H_{i}^{U}$ as measurement error), the condition $\pi_{1} \geq 0$ can still be true.
} 
female subsamples. We find that the magnitude of advantageous selection is larger for the females than for males.

We then propose a simple empirical strategy to combine MCBS and HRS data and examine the sources of advantageous selection. Our findings indicate that these sources include factors, such as income, education, and planning horizons, that a rich economic model of insurance purchase would typically accommodate. Interestingly, we find no evidence that variation in risk preferences, which is the primary focus of the theoretical literature on advantageous selection, explains the otherwise negative relationship between coverage and expenditure risk. Those who are less risk tolerant buy more insurance, but they are not particularly healthy.

But we do find that measures of cognitive ability and financial numeracy, which standard economic models do not accommodate, are important sources of advantageous selection. Those who are better able to calculate the costs and benefits of investments and insurance are both healthier, and more likely to buy the insurance. Our finding that cognitive ability is an important source of advantageous selection is consistent with a large literature suggesting that many senior citizens have difficulty understanding Medicare and Medigap benefit rules. This may suggest an important role for informational/educational interventions in this market to facilitate choice (see, e.g., Harris (2002)).

Our findings also suggest that heterogeneity in distributions, not merely expected levels of expenditure risk, should be included in models of asymmetric information. Specifically, we found that differences in the variance of health expenditure, which standard models of insurance purchase ignore, are related both to average expenditure risk and to insurance purchase. Our findings are robust to changes in the sample and the method of imputing expected medical expenditure.

Before discussing some implications of our results, we emphasize that they are specific to the Medigap insurance market. The heavily regulated nature of the Medigap market, as well as the natural link to the Medicare administrative data, make it a natural testing ground for advantageous selection. But, at the same time, these features of the Medigap market limit the generalizability of our quantitative findings to other markets.

One interesting implication of advantageous selection is that it may offer a unified explanation for why different insurance markets vary so much in size. We know from Akerlof (1970), Rothschild and Stiglitz (1976), and others that a severe adverse selection problem can cause an insurance market to be small or to not even exist. But advantageous selection on dimensions of private information other than ex post risk may counteract this effect. As we will now describe, this may explain why markets for automobile, health, home and life insurance are all large, while markets 
for annuities and long-term care insurance are quite small 58

At first, one might suspect that institutional details can explain size differences across these insurance markets. For example, in the U.S., automobile insurance is required by law for all vehicle owners; health insurance is frequently provided by employers; and social security is a mandatory annuity that crowds out private annuities. But, these explanations are not adequate for several reasons. First, there is neither government regulation nor widespread employer provision for life insurance in the U.S. (or in many other countries), and yet life insurance is a large and robust market. Conversely, neither Medicare nor Medigap provide (crowd out) long term care insurance, yet this market remains small 59 Second, for annuity markets, theoretical results by Yaari (1965) and Davidoff, Brown and Diamond (2005) show that large welfare gains can be achieved by additional annuitization even given social security. Finally, when one looks across a range of developed countries, one notes that size differences among insurance markets are very similar, despite different institutional details. Thus, a more unified explanation is called for.

To illustrate how selection based on multi-dimensional private information provides a potential unified explanation for size differences across insurance markets, it is useful to contrast the life and annuity insurance markets. These markets cover opposite risks: life insurance covers the risk of mortality while annuities cover the risk of longevity. In life insurance markets, the "bad risks" from an insurer's viewpoint are people with higher mortality probabilities. In a uni-dimensional model, less healthy people should have a greater demand for life insurance. But, it is plausible that more cognitively able people or those with more income also demand more life insurance, and tend to be healthier because they invest more in their health (similar to what we find in the health insurance market). If these two forces roughly balance, it is possible that overall there is no positive correlation between life insurance coverage and ex post mortality risk, as empirically found by Cawley and Philipson (1999). Given the lack of adverse selection in the aggregate, this market can be expected to be large.

In contrast, in an annuity insurance market, the "bad risks" from an insurer's viewpoint are healthy people who expect to live long lives. People with private information that they are relatively healthy should be more likely to purchase annuities, creating an adverse selection problem. Now lets assume, as before, that (i) more cognitively able people and those with more income are more

\footnotetext{
${ }^{58}$ See Finklestein and Poterba (2004) for some discussion about the size of annuity markets. Finkelstein and McGarry (2005) report that only about ten percent of elderly had long-term care insurance in their data.

${ }^{59}$ Brown and Finkelstein (2004) argued that supply-side imperfections can not explain the limited size of LTC insurance market. Note that Medicaid covers LTC once a person spends down assets to a near poverty level. Thus, LTC insurance is best thought of as asset preservation insurance.
} 
likely to purchase annuities, just as they are more likely to purchase health or life insurance, and (ii) more cognitively able people and those with more income are healthier and live longer, because they invest more in their health. This creates an additional source of adverse selection.

Thus, while selection based on cognitive ability and income worked to alleviate the problem of adverse selection based on health risk in the life insurance market, it works to exacerbate the adverse selection problem in the annuity market. Similar patterns hold when we look at the other markets we mention above (auto, health, long-term care). That is, in markets where we would expect selection based on cognitive ability or income to exacerbate selection based on risk type, the market is small, and vice-versa. Thus the theory of advantageous selection provides a plausible explanation of the size difference between life, annuity and other insurance markets without relying on institutional assumptions 60

Finally, while advantageous selection in an insurance market can cancel out the positive correlation between ex post risk and insurance coverage that arises in classic adverse selection models like Rothschild and Stiglitz (1976), it is important to emphasize that this does not mean there is no inefficiency in such a market. The policy implications of multidimensional selection models is an important topic for future research.

\section{References}

[1] Abbring, Jaap H., Pierre-André Chiappori, James J. Heckman and Jean Pinquet (2003). “Adverse Selection and Moral Hazard in Insurance: Can Dynamic Data Help to Distinguish?" Journal of European Economic Association Papers and Proceedings, Vol. 1, 512-521.

[2] Abbring, Jaap H., Pierre-André Chiappori and Jean Pinquet (2003). "Moral Hazard and Dynamic Insurance Data." Journal of the European Economic Association, Vol. 1, 767-820.

[3] Akerlof, George (1970). "The Market for 'Lemons': Quality Uncertainty and the Market Mechanism," Quarterly Journal of Economics, Vol. 84, 488-500.

[4] Arellano, Manuel and Costas Meghir (1992). "Female Labor Supply and On-the-Job Search: An Empirical Model Estimated Using Complementary Data Sets." Review of Economic Studies, Vol. 59, 537-557.

\footnotetext{
${ }^{60}$ Nevertheless, at this point these arguments are only speculative. Rigorous theoretical analysis of the relationship between equilibrium market size and the presence of advantageous selection is an interesting area for future research.
} 
[5] Angrist, Joshua D. and Alan B. Krueger (1992). "The Effect of Age at School Entry on Educational Attainment: An Application of Instrumental Variables with Moments From Two Samples." Journal of the American Statistical Association, Vol. 87,No. 418, 328-326.

[6] Araujo, Aloisio and Humberto Moreira (2001). "Non-Monotone Insurance Contracts and their Empirical Consequences." mimeo, IMPA, Brazil.

[7] Arrow, Kenneth (1963). "Uncertainty and the Welfare Economics of Medicare Care." American Economic Review, Vol. 53: 941-973.

[8] Barsky, Robert B., F. Thomas Juster, Miles Kimball and Matthew D. Shapiro (1997). "Preference Parameters and Behavioral Heterogeneity: An Experimental Approach in the Health and Retirement Study." Quarterly Journal of Economics, 537-379.

[9] Beliveau, Barbara C. (1984). "Theoretical and Empirical Aspects of Implicit Information in the Market for Life Insurance." Journal of Risk and Insurance. Vol. 51, No. 2, 286-307.

[10] Brown, Jeffrey and Amy Finkelstein (2004). "Supply or Demand? Why is the Market for Long-Term Care Insurance so Small?" NBER Working Paper No. 10782.

[11] Cafferata, Gail L. (1984). Knowledge of their Health Insurance Coverage by the Elderly. Medical Care, Vol. 22, No. 9 (September), 835-847.

[12] Cardon, James H. and Igal Hendel (2001). "Asymmetric Information in Health Insurance: Evidence from the National Medical Expenditure Survey." Rand Journal of Economics, Vol. 32, No. 3, 408-427.

[13] Cawley, John and Tomas Philipson (1999). "An Empirical Examination of Information Barriers to Trade in Insurance." American Economic Review, Vol. 89, No. 4, 827-846.

[14] Centers for Medicare and Medicaid Services (2004). Choosing a Medigap Policy: A Guide to Health Insurance for People with Medicare. U.S. Department of Health and Human Services, Baltimore, Maryland.

[15] Charles, Kerwin and Erik Hurst (2003). "The Correlation of Wealth Across Generations." Journal of Political Economy, Vol. 111, No. 6, 1155-1182.

[16] Chiappori, Pierre-André (2000). "Econometric Models of Insurance under Asymmetric Information." in Handbook of Insurance, edited by Georges Dionne, p. 365-394. 
[17] Chiappori, Pierre-André and Bernard Salanié (2000). "Testing for Asymmetric Information in Insurance Markets." Journal of Political Economy, Vol. 108, No. 1, 56-78.

[18] Chiappori, Pierre-André, Bruno Jullien, Benard Salanié and Francois Salanié (2005). "Asymmetric Information in Insurance: General Testable Implications." forthcoming, Rand Journal of Economics.

[19] Cohen, Alma (2005). "Asymmetric Information and Learning: Evidence from the Automobile Insurance Market." Review of Economics and Statistics, Vol. 87, No. 2, 197-207.

[20] Cohen, Alma and Liran Einav (2005). "Estimating Risk Preferences from Detuctible Choice." Working Paper, Stanford University.

[21] Cunningham, Peter J., Charles Denk and Michael Sinclair (2001). Do Consumers Know How their Health Plan Works? Health Affairs, Vol. 20, No. 2 (March/April), 159-166.

[22] Cutler, David, Amy Finkelstein and Kathleen McGarry (2006). "Preference Heterogeneity and Insurance Markets." mimeo, MIT.

[23] Dahlby, Bev G. (1983). "Adverse Selection and Statistical Discrimination: An Analysis of Canadian Automobile Insurance." Journal of Public Economics, Vol. 20, 121-130.

[24] Davidoff, Thomas, Jeffery R. Brown and Peter A. Diamond (2005). "Annuities and Individual Welfare." forthcoming, American Economic Review.

[25] Davidson, Bruce, Shoshanna Sofaer and Paul Gertler (1992). Consumer Demand and Biased Selection in the Demand for Coverage Supplementing Medicare. Social Science and Medicine, Vol. 34, No. 9, 1023-1034

[26] de Meza, David and David C. Webb (2001). "Advantageous Selection in Insurance Markets." Rand Journal of Economics, Vol. 32, No. 2, 249-262.

[27] Dionne, Georges, Christian Gouriéroux and Charles Vanasse (2001). "Testing for Evidence of Adverse Selection in Automobile Insurance Market: A Comment." Journal of Political Economy, Vol. 109, No. 2, 444-453.

[28] Ettner, Susan L. (1997). "Adverse Selection and the Purchase of Medigap Insurance by the Elderly." Journal of Health Economics, Vol. 16, 543-562. 
[29] Finkelstein, Amy and Kathleen McGarry (2003). "Private Information and its Effect on Market Equilibrium: New Evidence from Long-Term Care Insurance." NBER Working Paper 9957.

[30] Finkelstein, Amy and Kathleen McGarry (2006). "Multiple Dimensions of Private Information: Evidence from the Long-Term Care Insurance Market." forthcoming, American Economic Review.

[31] Finkelstein, Amy (2004). "Minimum Standards, Insurance Regulation and Adverse Selection: Evidence from the Medigap Market." mimeo, Harvard University.

[32] Finkelstein, Amy and James Poterba (2004). "Adverse Selection in Insurance Markets: Policyholder Evidence from the U.K. Annuity Market." Journal of Political Economy, Vol. 112, 183-208.

[33] Finkelstein, Amy and James Poterba (2006). "Testing for Adverse Selection with "Unused Observables." mimeo, Department of Economics, MIT.

[34] Gibbs, Deborah A., Judith A. Sangl and Barri Burrus (1996). Consumer Perspectives on Information Needs for Health Plan Choice. Health Care Financing Review, Vol. 18, No. 1, 55-73.

[35] Harris, Katherine M. (2002). Can High Quality Overcome Consumer Resistance to Restricted Provider Access? Evidence from a Health Plan Choice Experiment. Health Services Research, Vol. 37, No. 3, 551-71.

[36] Harris, Katherine and Michael Keane (1999). A Model of Health Plan Choice: Inferring Preferences and Perceptions from a Combination of Revealed Preference and Attitudinal Data, Journal of Econometrics, 89: 131-157.

[37] Hemenway, David (1990). "Propitious Selection." Quarterly Journal of Economics, Vol. 105, 1063-1069.

[38] Hemenway, David (1992). "Propitious Selection in Insurance." Journal of Risk and Uncertainty, Vol. 5, 247-251.

[39] Hurd, Michael D. and Kathleen McGarry (1997). "Medical Insurance and the Use of Health Care Services by the Elderly." Journal of Health Economics, Vol. 16, 129-154.

[40] Ichimura, Hidehiko and Elena Martinez-Sanchis (2004). "Identification and Estimation of GMM Models by Combining Two Data Sets.” Working Paper, University College London. 
[41] Isaacs, Stephen L. (1996). Consumer's Information Needs: Results of National Survey. Health Affairs, Vol. 15, No. 4, 31-41.

[42] Jullien, Bruno, Benard Salanié and Francois Salanié (2005). "Screening Risk Averse Agents Under Moral Hazard: Single-crossing and the CARA Case." forthcoming, Economic Theory.

[43] Juster, F. Thomas and Richard Suzman (1995). "An Overview of the Health and Retirement Study." Journal of Human Resources, Vol. 30, S7-S56.

[44] Kan, Kamhon (2003). "Residential Mobility and Job Changes Under Uncertainty." Journal of Urban Economics, Vol. 54, 566-586.

[45] Keane, Michael P. (2004). Modeling Health Insurance Choice Using the Heterogeneous Logit Model, manuscript, Yale University.

[46] Kezdi, G. and R.J. Willis (2005) "Who Becomes a Stockholder? Expectations, Subjective Uncertainty, and Asset Allocation." Mimeo, University of Michigan.

[47] Khandker, Rezaul K. and Lauren A. McCormack (1996). Enrollment and Utilization across Medicare Supplemental Plans. Report Submitted to the Health Care Financing Administration by the Center for Health Economics Research.

[48] Khandker Rezaul K. and Lauren A. McCormack (1999). "Medical Spending by Beneficiaries with Various Types of Supplemental Insurance." Medical Care Research and Review, Vol. 56, No. 2, 137-155.

[49] Khwaja, Ahmed (2005). "The Dynamic Trade-off Between Medical Expenditure Insurance, Moral Hazard and Mortality Risk: A Life Cycle Analysis of the Effects of Medicare on Individual Health Incentives and Health Outcomes," mimeo, Fuqua School of Business, Duke University.

[50] Kimball, Miles S., Claudia R. Sahm, and Matthew D. Shapiro (2005). "Using Survey-Based Risk Tolerance," mimeo, University of Michigan.

[51] Lusardi, Annamaria (1998). "On the Importance of the Precautionary Saving Motive." American Economic Review, Vol. 88 (2):449-54.

[52] Lillard, Lee A. and Jeannettte Rogowski (1995). "Does Supplemental Private Insurance Increase Medicare Costs?" Rand Corporation Working Paper Series 95-16. 
[53] McCall, Nelda, Thomas Rice and Judith Sangl (1986). Consumer Knowledge of Medicare and Supplemental Health Insurance Benefits. Health Services Research, Vol. 20, No. 6, 633-657.

[54] Pauly, Mark V. (1974). "Overinsurance and Public Provision of Insurance: The Roles of Moral Hazard and Adverse Selection." Quarterly Journal of Economics, Vol. 88, 44-62.

[55] Puelz, Robert and Arthur Snow (1994). "Evidence on Adverse Selection: Equilibrium Signaling and Cross-Subsidization in the Insurance Market." Journal of Political Economy, Vol. 102, No. $2,236-257$.

[56] Robst, John (2001). "Estimation of a Hedonic Pricing Model for Medigap Insurance." Unpublished Working Paper, Centers for Medicare and Medicaid Services.

[57] Rothschild, Michael and Joseph E. Stiglitz (1976). "Equilibrium in Competitive Insurance Markets: An Essay on the Economics of Imperfect Information," Quarterly Journal of Economics, Vol. 90, 629-649.

[58] Schmidt, Lucie (2006). "Risk Preferences and the Timing of Marriage and Childbearing." Williams College, Department of Economics Working Paper.

[59] Tumlinson, Anne, Hannah Bottigheimer, Peter Mahoney, Elliot Stone and Ann Hendricks (1997). Choosing a Health Plan: What Information will Consumers Use? Health Affairs, Vol. 16, No. 3, 229-238.

[60] Wilson, Charles (1977). "A Model of Insurance Markets with Incomplete Information." Journal of Economic Theory, Vol. 16, 167-207.

[61] Wolfe, John R. and John H. Goddeeris (1991). "Adverse Selection, Moral Hazard and Wealth Effects in the Medigap Insurance Market," Journal of Health Economics, Vol. 10, 433-459.

[62] Wooldridge, Jeffrey M. (2006). Introductory Econometrics: A Modern Approach. Third Edition, Thomson.

[63] Yaari, Menahem E. (1965). "Uncertain Lifetime, Life Insurance and the Theory of the Consumer." Review of Economic Studies, Vol. 32, 137-150. 
Table 1: Sample Characteristics: "Medigap" vs. "No Medigap"

\begin{tabular}{|c|c|c|c|c|c|c|}
\hline & \multicolumn{3}{|c|}{ MCBS } & \multicolumn{3}{|c|}{ HRS } \\
\hline & "Medigap 1" & "Medigap 2" & No "Medigap" & "Medigap 1" & "Medigap 2" & No "Medigap" \\
\hline Female & $\begin{array}{l}.606 \\
(.489)\end{array}$ & $\begin{array}{l}.587 \\
(.492)\end{array}$ & $\begin{array}{l}.599 \\
(.490)\end{array}$ & $\begin{array}{l}.583 \\
(.493)\end{array}$ & $\begin{array}{l}.554 \\
(.497)\end{array}$ & $\begin{array}{l}.562 \\
(.496)\end{array}$ \\
\hline Age & $\begin{array}{l}75.615 \\
(7.105)\end{array}$ & $\begin{array}{l}75.292 \\
(7.051)\end{array}$ & $\begin{array}{l}75.972 \\
(8.218)\end{array}$ & $\begin{array}{l}75.70 \\
(7.06)\end{array}$ & $\begin{array}{l}75.257 \\
(6.956)\end{array}$ & $\begin{array}{l}74.92 \\
(7.08)\end{array}$ \\
\hline Black & $\begin{array}{l}.032 \\
(.177)\end{array}$ & $\begin{array}{l}.041 \\
(.198)\end{array}$ & $\begin{array}{l}.142 \\
(.349)\end{array}$ & $\begin{array}{l}.029 \\
(.168)\end{array}$ & $\begin{array}{l}.036 \\
(.186)\end{array}$ & $\begin{array}{l}.120 \\
(.325)\end{array}$ \\
\hline Hispanic & $\begin{array}{l}.034 \\
(.181)\end{array}$ & $\begin{array}{l}.034 \\
(.180)\end{array}$ & $\begin{array}{l}.114 \\
(.317)\end{array}$ & $\begin{array}{l}.013 \\
(.113)\end{array}$ & $\begin{array}{l}.015 \\
(.121)\end{array}$ & $\begin{array}{l}.070 \\
(.256)\end{array}$ \\
\hline Income & $\begin{array}{l}32,003 \\
(46,299)\end{array}$ & $\begin{array}{l}33,292 \\
(45,067)\end{array}$ & $\begin{array}{l}20,760 \\
(42,281)\end{array}$ & $\begin{array}{l}23,838 \\
(31,113)\end{array}$ & $\begin{array}{l}29,176 \\
(39,094)\end{array}$ & $\begin{array}{l}19,231 \\
(28,687)\end{array}$ \\
\hline Married & $\begin{array}{l}.556 \\
(.497)\end{array}$ & $\begin{array}{l}.585 \\
(.493)\end{array}$ & $\begin{array}{l}.424 \\
(.494)\end{array}$ & $\begin{array}{l}.548 \\
(.498)\end{array}$ & $\begin{array}{l}.561 \\
(.496)\end{array}$ & $\begin{array}{l}.518 \\
(.500)\end{array}$ \\
\hline Widowed & $\begin{array}{l}.353 \\
(.478)\end{array}$ & $\begin{array}{l}.327 \\
(.469)\end{array}$ & $\begin{array}{l}.402 \\
(.490)\end{array}$ & $\begin{array}{l}.354 \\
(.478)\end{array}$ & $\begin{array}{l}.337 \\
(.473)\end{array}$ & $\begin{array}{l}.347 \\
(.476)\end{array}$ \\
\hline Divorced & $\begin{array}{l}.054 \\
(.225)\end{array}$ & $\begin{array}{l}.052 \\
(.222)\end{array}$ & $\begin{array}{l}.101 \\
(.301)\end{array}$ & $\begin{array}{l}.065 \\
(.246)\end{array}$ & $\begin{array}{l}.066 \\
(.249)\end{array}$ & $\begin{array}{l}.092 \\
(.289)\end{array}$ \\
\hline Less than HS & $\begin{array}{l}.253 \\
(.330)\end{array}$ & $\begin{array}{l}.242 \\
(.326)\end{array}$ & $\begin{array}{l}.419 \\
(.406)\end{array}$ & $\begin{array}{l}.261 \\
(.339)\end{array}$ & $\begin{array}{l}.236 \\
(.321)\end{array}$ & $\begin{array}{l}.349 \\
(.379)\end{array}$ \\
\hline High School & $\begin{array}{l}.309 \\
(.462)\end{array}$ & $\begin{array}{l}.299 \\
(.458)\end{array}$ & $\begin{array}{l}.247 \\
(.432)\end{array}$ & $\begin{array}{l}.392 \\
(.488)\end{array}$ & $\begin{array}{l}.374 \\
(.484)\end{array}$ & $\begin{array}{l}.336 \\
(.472)\end{array}$ \\
\hline Some College & $\begin{array}{l}.248 \\
(.432)\end{array}$ & $\begin{array}{l}.256 \\
(.436)\end{array}$ & $\begin{array}{l}.177 \\
(.382)\end{array}$ & $\begin{array}{l}.187 \\
(.390)\end{array}$ & $\begin{array}{l}.188 \\
(.391)\end{array}$ & $\begin{array}{l}.166 \\
(.373)\end{array}$ \\
\hline College & $\begin{array}{l}.104 \\
(.305)\end{array}$ & $\begin{array}{l}.109 \\
(.312)\end{array}$ & $\begin{array}{l}.062 \\
(.241)\end{array}$ & $\begin{array}{l}.081 \\
(.272)\end{array}$ & $\begin{array}{l}.092 \\
(.289)\end{array}$ & $\begin{array}{l}.079 \\
(.270)\end{array}$ \\
\hline Working & $\begin{array}{l}.146 \\
(.353)\end{array}$ & $\begin{array}{l}.145 \\
(.352)\end{array}$ & $\begin{array}{l}.106 \\
(.307)\end{array}$ & $\begin{array}{l}.139 \\
(.346)\end{array}$ & $\begin{array}{l}.138 \\
(.345)\end{array}$ & $\begin{array}{l}.135 \\
(.342)\end{array}$ \\
\hline $\begin{array}{l}\text { Total Medical } \\
\text { Expenditure }\end{array}$ & $\begin{array}{l}8,362 \\
(14,535)\end{array}$ & $\begin{array}{l}8,413 \\
(14,324)\end{array}$ & $\begin{array}{l}12,646 \\
(21,843)\end{array}$ & $\ldots$ & $\ldots$ & $\ldots$ \\
\hline $\begin{array}{l}\text { Medicare } \\
\text { Reimbursement }\end{array}$ & $\begin{array}{l}4,761 \\
(11,462)\end{array}$ & $\begin{array}{l}4,665 \\
(11,292)\end{array}$ & $\begin{array}{l}4,533 \\
(13,393)\end{array}$ & $\ldots$ & $\ldots$ & $\ldots$ \\
\hline
\end{tabular}

Note: Statistics are calculated using cross section sample weights. Standard deviations are in parenthesis. Number of observations vary by variable and sample. 
Table 2: Characteristics of Samples not Included in One of the Definitions of Medigap

\begin{tabular}{|c|c|c|c|}
\hline & $\begin{array}{l}\text { Covered by } \\
\text { Medicaid }\end{array}$ & $\begin{array}{l}\text { Employer } \\
\text { Sponsored } \\
\text { Insurance }\end{array}$ & $\begin{array}{c}\text { Sponsored } \\
\text { Insurance with } \\
<=\$ 500\end{array}$ \\
\hline Female & $\begin{array}{l}.633 \\
(.482)\end{array}$ & $\begin{array}{l}.532 \\
(.499)\end{array}$ & $\begin{array}{l}.533 \\
(.499)\end{array}$ \\
\hline Age & $\begin{array}{l}67.46 \\
(17.21)\end{array}$ & $\begin{array}{l}72.42 \\
(9.53)\end{array}$ & $\begin{array}{l}72.32 \\
(9.60)\end{array}$ \\
\hline Black & $\begin{array}{l}.209 \\
(.406)\end{array}$ & $\begin{array}{l}.064 \\
(.246)\end{array}$ & $\begin{array}{l}.067 \\
(.250)\end{array}$ \\
\hline Hispanic & $\begin{array}{l}.154 \\
(.361)\end{array}$ & $\begin{array}{l}.040 \\
(.196)\end{array}$ & $\begin{array}{l}.042 \\
(.201)\end{array}$ \\
\hline Married & $\begin{array}{l}.211 \\
(.408)\end{array}$ & $\begin{array}{l}.656 \\
(.475)\end{array}$ & $\begin{array}{l}.653 \\
(.476)\end{array}$ \\
\hline Widowed & $\begin{array}{l}.378 \\
(.485)\end{array}$ & $\begin{array}{l}.239 \\
(.427)\end{array}$ & $\begin{array}{l}.234 \\
(.423)\end{array}$ \\
\hline Divorced & $\begin{array}{l}.153 \\
(.360)\end{array}$ & $\begin{array}{l}.060 \\
(.237)\end{array}$ & $\begin{array}{l}.066 \\
(.248)\end{array}$ \\
\hline Less than HS & $\begin{array}{l}.520 \\
(.438)\end{array}$ & $\begin{array}{l}.211 \\
(.303)\end{array}$ & $\begin{array}{l}.214 \\
(.306)\end{array}$ \\
\hline High School & $\begin{array}{l}.207 \\
(.405)\end{array}$ & $\begin{array}{l}.303 \\
(.460)\end{array}$ & $\begin{array}{l}.327 \\
(.469)\end{array}$ \\
\hline Some College & $\begin{array}{l}.110 \\
(.313)\end{array}$ & $\begin{array}{l}.271 \\
(.445)\end{array}$ & $\begin{array}{l}.264 \\
(.441)\end{array}$ \\
\hline College & $\begin{array}{l}.032 \\
(.177)\end{array}$ & $\begin{array}{l}.107 \\
(.309)\end{array}$ & $\begin{array}{l}.095 \\
(.293)\end{array}$ \\
\hline Working & $\begin{array}{l}.040 \\
(.196)\end{array}$ & $\begin{array}{l}.129 \\
(.335)\end{array}$ & $\begin{array}{l}.119 \\
(.324)\end{array}$ \\
\hline $\begin{array}{l}\text { Total Medical } \\
\text { Expenditure }\end{array}$ & $\begin{array}{l}18,997 \\
(29,750)\end{array}$ & $\begin{array}{l}8,828 \\
(15,195)\end{array}$ & $\begin{array}{l}8,855 \\
(14,870)\end{array}$ \\
\hline $\begin{array}{l}\text { Medicare } \\
\text { Reimbursement }\end{array}$ & $\begin{array}{l}7,860 \\
(17,487) \\
\end{array}$ & $\begin{array}{l}4,365 \\
(10,804) \\
\end{array}$ & $\begin{array}{l}4,498 \\
(10,989) \\
\end{array}$ \\
\hline \# Obs. & 5,811 & 6,248 & 3,169 \\
\hline
\end{tabular}

Note: Statistics are calculated using cross section sample weights. Standard deviations are in parenthesis. Both MCBS and HRS samples are included. 
Table 3: OLS Regression Results of Total Medical Expenditure on "Medigap" Coverage in MCBS, with No Health Controls

\begin{tabular}{|c|c|c|c|c|c|c|}
\hline & \multicolumn{6}{|c|}{ Panel A: First "Medigap" Definition } \\
\hline & $(1)$ & $(2)$ & $(3)$ & $(4)$ & $(5)$ & $(6)$ \\
\hline Variables & All & Female & Male & All & Female & Male \\
\hline medigap & $\begin{array}{l}-4392.7^{\star \star \star} \\
(347.0)\end{array}$ & $\begin{array}{l}-6037.4^{\star \star \star} \\
(456.6)\end{array}$ & $\begin{array}{l}-1863.4^{\star \star \star} \\
(540.8)\end{array}$ & $\begin{array}{l}-3783.3^{\star \star \star} \\
(375.4)\end{array}$ & $\begin{array}{l}-5687.4^{\star \star \star} \\
(485.7)\end{array}$ & $\begin{array}{l}-1448.2^{\star \star \star} \\
(569.8)\end{array}$ \\
\hline female & $\begin{array}{l}270.0 \\
(356.7)\end{array}$ & & & $\begin{array}{l}-263.6 \\
(389.5)\end{array}$ & & \\
\hline (age-65) & $\begin{array}{l}387.5^{\star \star \star} \\
(138.2)\end{array}$ & $\begin{array}{l}460.6^{\star \star \star} \\
(176.0)\end{array}$ & $\begin{array}{l}292.9 \\
(229.3)\end{array}$ & $\begin{array}{l}310.5^{\star *} \\
(136.4)\end{array}$ & $\begin{array}{l}325.1^{\star *} \\
(169.1)\end{array}$ & $\begin{array}{l}281.8 \\
(229.6)\end{array}$ \\
\hline$($ age-65)^2 & $\begin{array}{l}1.94 \\
(10.65)\end{array}$ & $\begin{array}{l}-1.79 \\
(13.20)\end{array}$ & $\begin{array}{l}5.58 \\
(18.84)\end{array}$ & $\begin{array}{l}.94 \\
(10.5)\end{array}$ & $\begin{array}{l}-.744 \\
(12.7)\end{array}$ & $\begin{array}{l}.444 \\
(18.6)\end{array}$ \\
\hline$($ age-65)^3 & $\begin{array}{l}.12 \\
(.22) \\
\end{array}$ & $\begin{array}{l}.17 \\
(.27) \\
\end{array}$ & $\begin{array}{l}.07 \\
(.43) \\
\end{array}$ & $\begin{array}{l}.134 \\
(.220) \\
\end{array}$ & $\begin{array}{l}.160 \\
(.262) \\
\end{array}$ & $\begin{array}{l}.143 \\
(.422) \\
\end{array}$ \\
\hline \multirow[t]{2}{*}{ Adjusted R^2 } & $\begin{array}{l}15,945 \\
.0702 \\
\end{array}$ & $\begin{array}{l}9,725 \\
.0873 \\
\end{array}$ & $\begin{array}{l}6,220 \\
.0531 \\
\end{array}$ & $\begin{array}{l}15,784 \\
.0869 \\
\end{array}$ & $\begin{array}{l}9,621 \\
.1089 \\
\end{array}$ & $\begin{array}{l}6,163 \\
.0680 \\
\end{array}$ \\
\hline & \multicolumn{6}{|c|}{ Panel B: Second "Medigap" Definition } \\
\hline medigap & $\begin{array}{l}-4142.6^{\star \star \star} \\
(323.4)\end{array}$ & $\begin{array}{l}-5883.1^{\star \star \star} \\
(432.2)\end{array}$ & $\begin{array}{l}-1629.3^{\star \star \star} \\
(494.9)\end{array}$ & $\begin{array}{l}-3457.2^{\star \star \star} \\
(351.4)\end{array}$ & $\begin{array}{l}-5520^{\star \star \star} \\
(470.2)\end{array}$ & $\begin{array}{l}-1297^{\star \star \star} \\
(512.0)\end{array}$ \\
\hline female & $\begin{array}{l}-35.4 \\
(313.1)\end{array}$ & & & $\begin{array}{l}-545.5^{\star} \\
(338.0)\end{array}$ & & \\
\hline (age-65) & $\begin{array}{l}425.2^{\star \star \star} \\
(122.2)\end{array}$ & $\begin{array}{l}470.4^{\star \star \star} \\
(156.3)\end{array}$ & $\begin{array}{l}383.9 * \\
(198.1)\end{array}$ & $\begin{array}{l}333.6^{\star \star \star} \\
(120.7)\end{array}$ & $\begin{array}{l}336.8^{\star \star} \\
(150.8)\end{array}$ & $\begin{array}{l}336.2^{\star} \\
(197.3)\end{array}$ \\
\hline$($ age-65)^2 & $\begin{array}{l}-4.12 \\
(9.55)\end{array}$ & $\begin{array}{l}-5.85 \\
(11.90)\end{array}$ & $\begin{array}{l}-3.37 \\
(16.62)\end{array}$ & $\begin{array}{l}-3.75 \\
(9.37)\end{array}$ & $\begin{array}{l}-4.42 \\
(11.5)\end{array}$ & $\begin{array}{l}-5.64 \\
(16.32)\end{array}$ \\
\hline$($ age-65)^3 & $\begin{array}{l}.25 \\
(.21) \\
\end{array}$ & $\begin{array}{l}.26 \\
(.25) \\
\end{array}$ & $\begin{array}{l}.23 \\
(.39) \\
\end{array}$ & $\begin{array}{l}.237 \\
(.201) \\
\end{array}$ & $\begin{array}{l}.246 \\
(.240) \\
\end{array}$ & $\begin{array}{l}.250 \\
(.379) \\
\end{array}$ \\
\hline $\begin{array}{l}\text { \# of Observations } \\
\text { Adjusted } R^{\wedge} 2\end{array}$ & $\begin{array}{l}18,708 \\
.0638 \\
\end{array}$ & $\begin{array}{l}11,218 \\
.0830 \\
\end{array}$ & $\begin{array}{l}7,490 \\
.0442 \\
\end{array}$ & $\begin{array}{l}18,539 \\
.0787 \\
\end{array}$ & $\begin{array}{l}11,112 \\
.1024 \\
\end{array}$ & $\begin{array}{l}7,427 \\
.0588 \\
\end{array}$ \\
\hline $\begin{array}{l}\text { State Dummy } \\
\text { Year Dummy }\end{array}$ & $\begin{array}{l}\overline{Y e s} \\
\text { Yes }\end{array}$ & $\begin{array}{l}\text { Yes } \\
\text { Yes }\end{array}$ & $\begin{array}{l}\text { Yes } \\
\text { Yes }\end{array}$ & $\begin{array}{l}\text { Yes } \\
\text { Yes }\end{array}$ & $\begin{array}{l}\text { Yes } \\
\text { Yes }\end{array}$ & $\begin{array}{l}\text { Yes } \\
\text { Yes }\end{array}$ \\
\hline Other Demographic Controls & No & No & No & Yes & Yes & Yes \\
\hline
\end{tabular}

Note: The Dependent variable is "Total Medical Expenditure." All regressions are weighted by the cross section sample weight. See text and Data Appendix for the two definitions of Medigap.

Other demographics included are race, education, marital status, income, working and number of children.

Robust standard errors in parenthesis are clustered at individual level.

${ }^{*},{ }^{* *}$ and ${ }^{* *}$ denote significance at $10 \%, 5 \%$ and $1 \%$ respectively. 
Table 4: OLS Regression Results of Total Medical Expenditure on "Medigap" Coverage in MCBS, with Direct Health Controls

\begin{tabular}{|c|c|c|c|c|c|c|}
\hline & \multicolumn{6}{|c|}{ Panel A: First "Medigap" Definition } \\
\hline & $(1)$ & $(2)$ & $(3)$ & $(4)$ & $(5)$ & $(6)$ \\
\hline Variables & All & Female & Male & All & Female & Male \\
\hline medigap & $\begin{array}{l}1937.0^{\star \star \star} \\
(257.6)\end{array}$ & $\begin{array}{l}1677.3^{\star \star \star} \\
(349.0)\end{array}$ & $\begin{array}{l}2420.9^{\star \star \star} \\
(397.4)\end{array}$ & $\begin{array}{l}1732.8^{\star \star \star} \\
(272.4)\end{array}$ & $\begin{array}{l}1426.2^{\star \star \star} \\
(358.4)\end{array}$ & $\begin{array}{l}2210.1^{\star \star \star} \\
(418.9)\end{array}$ \\
\hline female & $\begin{array}{l}-751.6^{\star \star \star} \\
(283.7)\end{array}$ & & & $\begin{array}{l}-754.1^{\star \star \star} \\
(294.0)\end{array}$ & & \\
\hline (age-65) & $\begin{array}{l}394.5^{\star \star \star} \\
(117.4)\end{array}$ & $\begin{array}{l}417.5^{\star \star \star} \\
(145.0)\end{array}$ & $\begin{array}{l}355.4^{*} \\
(197.6)\end{array}$ & $\begin{array}{l}419.6^{\star \star \star} \\
(113.3)\end{array}$ & $\begin{array}{l}444.2^{\star \star \star} \\
(137.4)\end{array}$ & $\begin{array}{l}392.1^{\star *} \\
(198.9)\end{array}$ \\
\hline$($ age-65)^2 & $\begin{array}{l}-27.5^{\star \star \star} \\
(9.3)\end{array}$ & $\begin{array}{l}-32.0^{\star \star \star} \\
(11.4)\end{array}$ & $\begin{array}{l}-22.8 \\
(16.3)\end{array}$ & $\begin{array}{l}-28.3^{\star \star \star} \\
(9.0)\end{array}$ & $\begin{array}{l}-32.7^{\star \star \star} \\
(11.1)\end{array}$ & $\begin{array}{l}-25.2 \\
(16.4)\end{array}$ \\
\hline$($ age-65)^3 & $\begin{array}{l}.474^{\star \star} \\
(.207) \\
\end{array}$ & $\begin{array}{l}.548^{* *} \\
(.254) \\
\end{array}$ & $\begin{array}{l}.466 \\
(.380) \\
\end{array}$ & $\begin{array}{l}.491^{\star *} \\
(.202) \\
\end{array}$ & $\begin{array}{l}.562^{\star \star} \\
(.247) \\
\end{array}$ & $\begin{array}{l}.520 \\
(.382) \\
\end{array}$ \\
\hline \# of Observations & 14,129 & 8,371 & 5,758 & 14,105 & 8,365 & 5,740 \\
\hline \multirow[t]{2}{*}{ Adjusted $\mathrm{R}^{\wedge} 2$} & .2087 & .1915 & .2462 & .2135 & .2007 & .2484 \\
\hline & \multicolumn{6}{|c|}{ Panel B: Second "Medigap" Definition } \\
\hline medigap & $\begin{array}{l}1967.3^{\star \star \star} \\
(238.7)\end{array}$ & 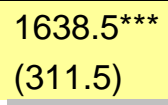 & $\begin{array}{l}2529.7^{\star \star \star} \\
(377.4)\end{array}$ & $\begin{array}{l}1760.2^{\star \star \star} \\
(255.9)\end{array}$ & $\begin{array}{l}1372.5^{\star \star \star} \\
(330.0)\end{array}$ & $\begin{array}{l}2353.1^{\star \star \star} \\
(398.3)\end{array}$ \\
\hline female & $\begin{array}{l}-926.1^{\star \star \star} \\
(264.0)\end{array}$ & & & $\begin{array}{l}-911.9^{\star \star \star} \\
(275.7)\end{array}$ & & \\
\hline (age-65) & $\begin{array}{l}371.6^{\star \star \star} \\
(104.1)\end{array}$ & $\begin{array}{l}404.5^{\star \star \star} \\
(129.2)\end{array}$ & $\begin{array}{l}371.8^{\star \star} \\
(171.1)\end{array}$ & $\begin{array}{l}384.3^{\star \star \star} \\
(101.8)\end{array}$ & $\begin{array}{l}417.5^{\star \star \star} \\
(124.0)\end{array}$ & $\begin{array}{l}392.6^{\star \star} \\
(172.0)\end{array}$ \\
\hline$($ age-65)^2 & $\begin{array}{l}-25.6^{\star \star \star} \\
(8.3)\end{array}$ & $\begin{array}{l}-30.2^{\star \star \star} \\
(10.2)\end{array}$ & $\begin{array}{l}-24.8^{\star} \\
(14.1)\end{array}$ & $\begin{array}{l}-25.6^{\star \star \star} \\
(8.1)\end{array}$ & $\begin{array}{l}-30.3^{\star \star \star} \\
(9.9)\end{array}$ & $\begin{array}{l}-26.3^{\star} \\
(14.1)\end{array}$ \\
\hline$($ age-65)^3 & $\begin{array}{l}.418^{\star \star \star} \\
(.185) \\
\end{array}$ & $\begin{array}{l}.504^{\star \star} \\
(.227) \\
\end{array}$ & $\begin{array}{l}.479 \\
(.330) \\
\end{array}$ & $\begin{array}{l}.420 * \star \\
(.182) \\
\end{array}$ & $\begin{array}{l}.506^{\star *} \\
(.222) \\
\end{array}$ & $\begin{array}{l}.520 \\
(.331) \\
\end{array}$ \\
\hline $\begin{array}{l}\text { \# of Observations } \\
\text { Adjusted } \mathrm{R}^{\wedge} 2\end{array}$ & $\begin{array}{l}16,885 \\
.2001\end{array}$ & $\begin{array}{l}9,860 \\
.1906\end{array}$ & $\begin{array}{l}7,025 \\
.2342\end{array}$ & $\begin{array}{l}16,853 \\
.2042\end{array}$ & $\begin{array}{l}9,852 \\
.1991\end{array}$ & $\begin{array}{l}7,001 \\
.2362\end{array}$ \\
\hline $\begin{array}{l}\text { State Dummy } \\
\text { Year Dummy }\end{array}$ & $\begin{array}{l}\text { Yes } \\
\text { Yes }\end{array}$ & $\begin{array}{l}\text { Yes } \\
\text { Yes }\end{array}$ & $\begin{array}{l}\text { Yes } \\
\text { Yes }\end{array}$ & $\begin{array}{l}\text { Yes } \\
\text { Yes }\end{array}$ & $\begin{array}{l}\text { Yes } \\
\text { Yes }\end{array}$ & $\begin{array}{l}\text { Yes } \\
\text { Yes }\end{array}$ \\
\hline Other Demographic Controls & No & No & No & Yes & Yes & Yes \\
\hline
\end{tabular}

Note: The Dependent variable is "Total Medical Expenditure." All regressions are weighted by the cross section sample weight. See text and Data Appendix for the two definitions of Medigap.

The variables included as direct health controls are detailed in Data Appendix. The other demographics included are race, education, marital status, income, working and number of children.

Robust standard errors in parenthesis are clustered at individual level.

${ }^{*},{ }^{* *}$ and ${ }^{* \star *}$ denote significance at $10 \%, 5 \%$ and $1 \%$ respectively. 
Table 5: OLS Regression Results of Total Medical Expenditure on "Medigap" Coverage in MCBS, with Controls for Health Factors

\begin{tabular}{|c|c|c|c|c|c|c|}
\hline & \multicolumn{6}{|c|}{ Panel A: First "Medigap" Definition } \\
\hline & $(1)$ & $(2)$ & $(3)$ & $(4)$ & $(5)$ & (6) \\
\hline Variables & All & Female & Male & All & Female & Male \\
\hline medigap & $\begin{array}{l}2083.3^{\star \star \star} \\
(280.6)\end{array}$ & $\begin{array}{l}1601.1^{\star \star \star} \\
(353.8)\end{array}$ & $\begin{array}{l}2775.5^{\star \star \star} \\
(426.3)\end{array}$ & 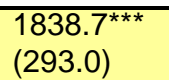 & $\begin{array}{l}1347.5^{\star \star \star} \\
(361.7)\end{array}$ & $\begin{array}{l}2450.0^{\star \star \star} \\
(453.5)\end{array}$ \\
\hline female & $\begin{array}{l}-1311.2^{\star \star \star} \\
(271.5)\end{array}$ & & & $\begin{array}{l}-1274.4^{\star \star \star} \\
(285.4)\end{array}$ & & \\
\hline (age-65) & $\begin{array}{l}421.8^{\star \star \star} \\
(118.7)\end{array}$ & $\begin{array}{l}447.6^{\star \star \star} \\
(151.5)\end{array}$ & $\begin{array}{l}436.0^{\star *} \\
(194.2)\end{array}$ & $\begin{array}{l}433.5^{\star \star \star} \\
(116.9)\end{array}$ & $\begin{array}{l}467.8^{\star \star \star} \\
(144.2)\end{array}$ & $\begin{array}{l}451.6^{\star *} \\
(196.6)\end{array}$ \\
\hline$(\text { age }-65)^{\wedge} 2$ & $\begin{array}{l}-28.7^{\star \star * *} \\
(9.2)\end{array}$ & $\begin{array}{l}-32.6^{\star \star \star} \\
(11.9)\end{array}$ & $\begin{array}{l}-27.3^{*} \\
(16.0)\end{array}$ & $\begin{array}{l}-28.6^{\star \star \star} \\
(9.1)\end{array}$ & $\begin{array}{l}-32.3^{\star \star \star} \\
(11.6)\end{array}$ & $\begin{array}{l}-26.7^{*} \\
(16.2)\end{array}$ \\
\hline$(\operatorname{age}-65)^{\wedge} 3$ & $\begin{array}{l}.479^{\star *} \\
(.205)\end{array}$ & $\begin{array}{l}.534^{\star *} \\
(.261)\end{array}$ & $\begin{array}{l}.543 \\
(.375)\end{array}$ & $\begin{array}{l}.481^{\star \star} \\
(.201)\end{array}$ & $\begin{array}{l}.513^{\star *} \\
(.255)\end{array}$ & $\begin{array}{l}.520 \\
(.381)\end{array}$ \\
\hline Factor1 & $\begin{array}{l}321.0 \\
(498.0)\end{array}$ & $\begin{array}{l}-410.7^{\star \star \star} \\
(89.0)\end{array}$ & $\begin{array}{l}1097.1^{*} \\
(658.7)\end{array}$ & $\begin{array}{l}324.9 \\
(495.1)\end{array}$ & $\begin{array}{l}-415.5^{\star \star \star} \\
(90.3)\end{array}$ & $\begin{array}{l}1094.5^{*} \\
(662.0)\end{array}$ \\
\hline Factor2 & $\begin{array}{l}4917.5^{\star \star \star} \\
(268.3)\end{array}$ & $\begin{array}{l}4902.2^{\star \star \star} \\
(343.2)\end{array}$ & $\begin{array}{l}4880.6^{\star \star \star} \\
(368.4)\end{array}$ & $\begin{array}{l}4928.9 * \star \star \\
(269.3)\end{array}$ & $\begin{array}{l}4976.5^{\star \star \star} \\
(349.4)\end{array}$ & $\begin{array}{l}4855.9^{\star \star \star} \\
(357.9)\end{array}$ \\
\hline Factor3 & $\begin{array}{l}-2979.4^{\star * \star} \\
(306.2)\end{array}$ & $\begin{array}{l}-2500.8^{\star \star \star} \\
(300.7)\end{array}$ & $\begin{array}{l}-4048.4^{\star \star \star} \\
(623.9)\end{array}$ & $\begin{array}{l}-3055.1^{\star \star \star} \\
(308.0)\end{array}$ & $\begin{array}{l}-2449.8^{\star \star *} \\
(307.7)\end{array}$ & $\begin{array}{l}-4211.7^{\star \star \star} \\
(605.5)\end{array}$ \\
\hline Factor4 & $\begin{array}{l}-652.1^{\star *} \\
(311.1)\end{array}$ & $\begin{array}{l}-684.3^{\star} \\
(384.3)\end{array}$ & $\begin{array}{l}-1073.5 \\
(911.2)\end{array}$ & $\begin{array}{l}-746.3^{\star *} \\
(309.7)\end{array}$ & $\begin{array}{l}-794.9 * \star \\
(381.2)\end{array}$ & $\begin{array}{l}-1141.8 \\
(895.8)\end{array}$ \\
\hline Factor5 & $\begin{array}{l}75.8 \\
(305.0)\end{array}$ & $\begin{array}{l}436.4^{*} \\
(253.8)\end{array}$ & $\begin{array}{l}-2278.9^{\star} \\
(1340.1)\end{array}$ & $\begin{array}{l}28.7^{*} \\
(309.8)\end{array}$ & $\begin{array}{l}459.3^{*} \\
(252.8)\end{array}$ & $\begin{array}{l}-2294.7^{*} \\
(1308.9)\end{array}$ \\
\hline $\begin{array}{l}\text { \# of Observations } \\
\text { Adjusted } R^{\wedge} 2\end{array}$ & $\begin{array}{l}14,129 \\
.1398\end{array}$ & $\begin{array}{l}8,371 \\
.1345\end{array}$ & $\begin{array}{l}5,758 \\
.1792\end{array}$ & $\begin{array}{l}14,105 \\
.1448\end{array}$ & $\begin{array}{l}8,337 \\
.1450\end{array}$ & $\begin{array}{l}5,731 \\
.1857\end{array}$ \\
\hline & \multicolumn{6}{|c|}{ Panel B: Second "Medigap" Definition } \\
\hline medigap & $\begin{array}{l}2154.5^{\star \star \star} \\
(256.7)\end{array}$ & $\begin{array}{l}1577.6^{\star \star \star} \\
(321.1)\end{array}$ & $\begin{array}{l}2944.7^{\star \star \star} \\
(412.7)\end{array}$ & $\begin{array}{l}1914.2^{\star \star \star} \\
(207.8)\end{array}$ & $\begin{array}{l}1312.0^{\star \star \star} \\
(338.0)\end{array}$ & $\begin{array}{l}2628.6^{\star \star \star} \\
(426.4)\end{array}$ \\
\hline female & $\begin{array}{l}-1468.5^{\star \star \star} \\
(249.1)\end{array}$ & & & $\begin{array}{l}-1435.7^{\star \star \star} \\
(261.3)\end{array}$ & & \\
\hline (age-65) & $\begin{array}{l}433.1^{\star \star \star} \\
(105.0)\end{array}$ & $\begin{array}{l}442.3^{\star \star \star} \\
(134.7)\end{array}$ & $\begin{array}{l}421.8^{\star \star \star} \\
(168.2)\end{array}$ & $\begin{array}{l}434.9 * \star \star \\
(103.9)\end{array}$ & $\begin{array}{l}452.4^{\star \star \star} \\
(129.6)\end{array}$ & $\begin{array}{l}414.9 * \star \star \\
(170.6)\end{array}$ \\
\hline$(\operatorname{age}-65)^{\wedge} 2$ & $\begin{array}{l}-29.2^{\star * *} \\
(8.2)\end{array}$ & $\begin{array}{l}-31.6^{\star \star * *} \\
(10.6)\end{array}$ & $\begin{array}{l}-27.1^{\star *} \\
(13.7)\end{array}$ & $\begin{array}{l}-28.5^{\star \star \star *} \\
(8.1)\end{array}$ & $\begin{array}{l}-31.1^{\star \star * *} \\
(10.4)\end{array}$ & $\begin{array}{l}-25.2^{*} \\
(13.8)\end{array}$ \\
\hline$($ age-65)^3 & $\begin{array}{l}.468^{\star \star \star} \\
(.184)\end{array}$ & $\begin{array}{l}.508^{\star \star} \\
(.234)\end{array}$ & $\begin{array}{l}.484 \\
(.322)\end{array}$ & $\begin{array}{l}.461^{*} \\
(.181)\end{array}$ & $\begin{array}{l}.489 * * \\
(.230)\end{array}$ & $\begin{array}{l}.437 \\
(.325)\end{array}$ \\
\hline Factor1 & $\begin{array}{l}147.6 \\
(422.3)\end{array}$ & $\begin{array}{l}-843.9^{\star * \star} \\
(88.3)\end{array}$ & $\begin{array}{l}847.2 \\
(767.3)\end{array}$ & $\begin{array}{l}144.3 \\
(420.1)\end{array}$ & $\begin{array}{l}-865.8^{\star \star \star} \\
(89.0)\end{array}$ & $\begin{array}{l}878.8 \\
(808.3)\end{array}$ \\
\hline Factor2 & $\begin{array}{l}4908.8^{\star \star \star} \\
(246.2)\end{array}$ & $\begin{array}{l}4743.5^{\star \star \star} \\
(310.0)\end{array}$ & $\begin{array}{l}4982.6^{\star \star \star} \\
(360.9)\end{array}$ & $\begin{array}{l}4918.5^{\star \star \star} \\
(247.6)\end{array}$ & $\begin{array}{l}4820.0^{\star \star \star} \\
(316.7)\end{array}$ & $\begin{array}{l}4970.3^{\star \star \star} \\
(356.9)\end{array}$ \\
\hline Factor3 & $\begin{array}{l}-2949.4^{\star \star \star} \\
(265.3)\end{array}$ & $\begin{array}{l}-2578.1^{\star \star \star} \\
(264.4)\end{array}$ & $\begin{array}{l}-3560.8^{\star \star \star} \\
(515.9)\end{array}$ & $\begin{array}{l}-3008.7^{\star \star \star} \\
(266.5)\end{array}$ & $\begin{array}{l}-2537.1^{\star \star \star} \\
(269.2)\end{array}$ & $\begin{array}{l}-3701.8^{\star \star \star} \\
(518.7)\end{array}$ \\
\hline Factor4 & $\begin{array}{l}-435.3 \\
(266.3)\end{array}$ & $\begin{array}{l}-689.7^{* *} \\
(333.7)\end{array}$ & $\begin{array}{l}181.3 \\
(453.0)\end{array}$ & $\begin{array}{l}-510.9 * \\
(265.8)\end{array}$ & $\begin{array}{l}-771.5^{\star \star} \\
(331.3)\end{array}$ & $\begin{array}{l}216.9 \\
(458.2)\end{array}$ \\
\hline Factor5 & $\begin{array}{l}182.9 \\
(267.5)\end{array}$ & $\begin{array}{l}408.2^{*} \\
(229.2)\end{array}$ & $\begin{array}{l}-153.0 \\
(409.4)\end{array}$ & $\begin{array}{l}140.4 \\
(271.7)\end{array}$ & $\begin{array}{l}425.2^{*} \\
(227.9)\end{array}$ & $\begin{array}{l}-184.0 \\
(408.4)\end{array}$ \\
\hline $\begin{array}{l}\text { \# of Observations } \\
\text { Adjusted } \mathrm{R}^{\wedge} 2\end{array}$ & $\begin{array}{l}16,885 \\
.1401\end{array}$ & $\begin{array}{l}9,860 \\
.1357\end{array}$ & $\begin{array}{l}7,025 \\
.1548\end{array}$ & $\begin{array}{l}16,853 \\
.1447\end{array}$ & $\begin{array}{l}9,822 \\
.1451\end{array}$ & $\begin{array}{l}6991 \\
.1605\end{array}$ \\
\hline $\begin{array}{l}\text { State Dummy } \\
\text { Year Dummy }\end{array}$ & $\begin{array}{l}\text { Yes } \\
\text { Yes }\end{array}$ & $\begin{array}{l}\text { Yes } \\
\text { Yes }\end{array}$ & $\begin{array}{l}\text { Yes } \\
\text { Yes }\end{array}$ & $\begin{array}{l}\text { Yes } \\
\text { Yes }\end{array}$ & $\begin{array}{l}\text { Yes } \\
\text { Yes }\end{array}$ & $\begin{array}{l}\text { Yes } \\
\text { Yes }\end{array}$ \\
\hline Other Demographic Controls & No & No & No & Yes & Yes & Yes \\
\hline
\end{tabular}

Note: The Dependent variable is "Total Medical Expenditure." All regressions are weighted by the cross section sample weight. See text and Data Appendix for the two definitions of Medigap.

The variables included as direct health controls are detailed in Data Appendix. The other demographics included are race, education, marital status, income, working and number of children.

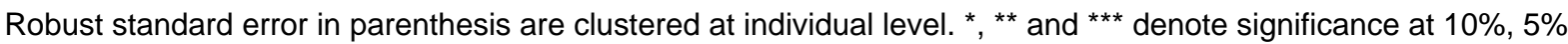
and $1 \%$ respectively. 
Table 6: Partial Correlation between "Medigap" Coverage and Health Factors in MCBS, Conditional on Gender and Age

\begin{tabular}{|c|c|c|c|c|c|c|c|c|c|c|c|c|}
\hline \multirow{3}{*}{ Factors } & \multicolumn{6}{|c|}{ "Panel A: First "Medigap" Definition } & \multicolumn{6}{|c|}{ Panel B: Second "Medigap" Definition } \\
\hline & \multicolumn{2}{|c|}{ All } & \multicolumn{2}{|c|}{ Female } & \multicolumn{2}{|c|}{ Male } & \multicolumn{2}{|c|}{ All } & \multicolumn{2}{|c|}{ Female } & \multicolumn{2}{|c|}{ Male } \\
\hline & EXP & PCORR & EXP & PCORR & EXP & PCORR & EXP & PCORR & EXP & PCORR & EXP & PCORR \\
\hline Factor1 & 321.0 & $\begin{array}{l}.0296 \\
(.000)\end{array}$ & $-410.7^{\star \star \star}$ & $\begin{array}{l}.0274 \\
(.012)\end{array}$ & $1097.1^{*}$ & $\begin{array}{l}.0342 \\
(.009)\end{array}$ & 147.6 & $\begin{array}{l}.0269 \\
(.000)\end{array}$ & $-843.9^{\star \star \star}$ & $\begin{array}{l}.0373 \\
(.000)\end{array}$ & 847.2 & $\begin{array}{l}.0267 \\
(.025)\end{array}$ \\
\hline Factor2 & $4917.5^{\star \star \star}$ & $\begin{array}{l}-.1166 \\
(.000)\end{array}$ & $4902.2^{\star \star \star}$ & $\begin{array}{l}-.1290 \\
(.000)\end{array}$ & $4880.6^{\star \star \star}$ & $\begin{array}{l}-.0978 \\
(.000)\end{array}$ & $4908.8^{\star \star \star}$ & $\begin{array}{l}-.1107 \\
(.000)\end{array}$ & $4743.5^{\star \star \star}$ & $\begin{array}{l}-.1193 \\
(.000)\end{array}$ & $4982.6^{\star \star \star}$ & $\begin{array}{l}-.0953 \\
(.000)\end{array}$ \\
\hline Factor3 & $-2979.4^{\star \star \star}$ & $\begin{array}{l}.0319 \\
(.000)\end{array}$ & $-2500.8^{\star \star \star}$ & $\begin{array}{l}.0425 \\
(.000)\end{array}$ & $-4048.4^{\star \star \star}$ & $\begin{array}{l}.0200 \\
(.129)\end{array}$ & $-2949.4^{\star \star \star}$ & $\begin{array}{l}.0297 \\
(.000)\end{array}$ & $-2578.1^{\star \star \star}$ & $\begin{array}{l}.0434 \\
(.000)\end{array}$ & $-3560.8^{\star \star \star}$ & $\begin{array}{l}.0138 \\
(.247)\end{array}$ \\
\hline Factor4 & $-652.1^{* \star}$ & $\begin{array}{l}-.0177 \\
(.035)\end{array}$ & $-684.3^{*}$ & $\begin{array}{l}-.0171 \\
(.117)\end{array}$ & -1073.5 & $\begin{array}{l}.0229 \\
(.083)\end{array}$ & -435.3 & $\begin{array}{l}-.0186 \\
(.016)\end{array}$ & $-689.7^{* *}$ & $\begin{array}{l}-.0157 \\
(.120)\end{array}$ & 181.3 & $\begin{array}{l}-.0389 \\
(.001)\end{array}$ \\
\hline Factor5 & 75.8 & $\begin{array}{l}.0207 \\
(.014)\end{array}$ & $436.4^{\star}$ & $\begin{array}{l}.0143 \\
(.190)\end{array}$ & $-2278.9^{*}$ & $\begin{array}{c}-.0204 \\
(.122)\end{array}$ & 182.9 & $\begin{array}{l}.0333 \\
(.015)\end{array}$ & $408.2^{*}$ & $\begin{array}{l}.0258 \\
(.010)\end{array}$ & -153.0 & $\begin{array}{l}.0262 \\
(.028)\end{array}$ \\
\hline \# of Obs. & & 14,131 & & 8,373 & & 5,758 & & 16,887 & & 9,862 & & 7,025 \\
\hline
\end{tabular}

Note: The columns labelled with "EXP" are the regression coefficients from Table 3 for the specification with other demographic controls. They are included in the table for the interpretation of the factors.

The columns labelled with "PORR" lists the partial correlation of "medigap" with the corresponding factors. The number in parenthesis is the significance level of the correlation. 
Table 7: Descripitive Statistics of MCBS and HRS Samples

\begin{tabular}{|c|c|c|c|c|c|c|c|c|c|c|c|c|}
\hline & \multicolumn{6}{|c|}{ Panel A: First Definition of Medigap } & \multicolumn{6}{|c|}{ Panel B: Second Definition of Medigap } \\
\hline & \multicolumn{3}{|c|}{ MCBS } & \multicolumn{3}{|c|}{ HRS } & \multicolumn{3}{|c|}{ MCBS } & \multicolumn{3}{|c|}{ HRS } \\
\hline & All & Female & Male & $\overline{\text { All }}$ & Female & Male & All & Female & Male & All & Female & Male \\
\hline \multirow[t]{2}{*}{ Female } & 0.602 & 1.000 & .000 & .572 & 1.000 & .000 & .593 & 1.000 & .000 & .558 & 1.000 & .000 \\
\hline & $(.489)$ & $(.000)$ & $(.000)$ & $(.495)$ & $(.000)$ & $(.000)$ & $(.491)$ & $(.000)$ & $(.000)$ & $(.497)$ & $(.000)$ & $(.000)$ \\
\hline \multirow[t]{2}{*}{ Age } & 75.808 & 76.546 & 74.690 & 75.301 & 75.847 & 74.415 & 75.602 & 76.336 & 74.534 & 75.112 & 75.672 & 74.263 \\
\hline & $(7.729)$ & (8.047) & (7.076) & (7.078) & (7.353) & $(6.611)$ & (7.612) & (7.933) & (6.983) & (7.010) & (7.295) & $(6.547)$ \\
\hline \multirow[t]{2}{*}{ Medigap } & .459 & .462 & .455 & .486 & .495 & .473 & .545 & .540 & .552 & .568 & .565 & .573 \\
\hline & $(.498)$ & $(.495)$ & $(.498)$ & $(.500)$ & $(.500)$ & $(.499)$ & $(.498)$ & $(.498)$ & $(.497)$ & $(.495)$ & $(.496)$ & $(.495)$ \\
\hline \multirow[t]{2}{*}{ Medicare_AB } & .958 & .966 & .945 & .949 & .947 & .953 & .955 & .965 & .940 & .948 & .947 & .949 \\
\hline & $(.201)$ & $(.181)$ & $(.228)$ & $(.219)$ & $(.223)$ & $(.213)$ & $(.208)$ & $(.185)$ & $(.237)$ & $(.223)$ & $(.224)$ & $(.220)$ \\
\hline \multirow[t]{2}{*}{ Black } & .091 & .094 & .087 & .076 & .082 & .069 & .087 & .090 & .082 & .072 & .078 & .065 \\
\hline & $(.288)$ & $(.293)$ & $(.282)$ & $(.265)$ & $(.274)$ & $(.253)$ & $(.281)$ & $(.286)$ & $(.275)$ & $(.259)$ & $(.269)$ & $(.246)$ \\
\hline \multirow[t]{2}{*}{ Hispanic } & .077 & .073 & .082 & .042 & .040 & .046 & .070 & .067 & .074 & .039 & .036 & .042 \\
\hline & $(.266)$ & $(.261)$ & $(.275)$ & $(.202)$ & $(.195)$ & $(.211)$ & $(.255)$ & $(.251)$ & $(.261)$ & $(.193)$ & $(.188)$ & $(.200)$ \\
\hline \multirow[t]{2}{*}{ Married } & .485 & .344 & .698 & .532 & .391 & .743 & .512 & .371 & .717 & .543 & .390 & .755 \\
\hline & $(.500)$ & $(.475)$ & $(.459)$ & $(.499)$ & $(.488)$ & $(.437)$ & $(.500)$ & $(.483)$ & $(.451)$ & $(.498)$ & $(.488)$ & $(.430)$ \\
\hline \multirow[t]{2}{*}{ Widowed } & .379 & .523 & .162 & .350 & .481 & .151 & .361 & .504 & .153 & .342 & .478 & .146 \\
\hline & $(.485)$ & $(.499)$ & $(.368)$ & $(.477)$ & $(.500)$ & $(.358)$ & $(.480)$ & $(.500)$ & $(.360)$ & $(.474)$ & $(.500)$ & $(.353)$ \\
\hline \multirow[t]{2}{*}{ Divorced } & .079 & .084 & .071 & .079 & .092 & .063 & .074 & .079 & .068 & .077 & .092 & .060 \\
\hline & $(.270)$ & $(.287)$ & $(.258)$ & $(.269)$ & $(.289)$ & $(.244)$ & $(.262)$ & $(.269)$ & $(.252)$ & $(.267)$ & $(.290)$ & $(.238)$ \\
\hline \multirow[t]{2}{*}{ \# of children } & 2.998 & 2.912 & 3.127 & 3.193 & 3.134 & 3.283 & 2.978 & 2.890 & 3.106 & 3.163 & 3.093 & 3.263 \\
\hline & $(2.238)$ & $(2.224)$ & $(2.252)$ & (2.228) & $(2.227)$ & (2.238) & (2.187) & (2.177) & (2.194) & (2.193) & (2.198) & (2.193) \\
\hline \multirow[t]{2}{*}{ Working } & .124 & .088 & .179 & .137 & .118 & .165 & .127 & .091 & .180 & .137 & .118 & .163 \\
\hline & $(.330)$ & $(.284)$ & $(.383)$ & $(.344)$ & $(.323)$ & $(.371)$ & $(.333)$ & $(.287)$ & $(.385)$ & $(.344)$ & $(.322)$ & $(.369)$ \\
\hline \multirow[t]{2}{*}{ Less than HS } & .343 & .342 & .345 & .306 & .306 & .307 & .323 & .322 & .323 & .285 & .287 & .280 \\
\hline & $(.377)$ & $(.375)$ & $(.384)$ & $(.360)$ & $(.362)$ & $(.361)$ & $(.368)$ & $(.367)$ & $(.368)$ & $(.348)$ & $(.350)$ & $(.347)$ \\
\hline \multirow[t]{2}{*}{ High School } & .276 & .300 & .240 & .363 & .387 & .329 & .276 & .300 & .240 & .357 & .382 & .324 \\
\hline & $(.447)$ & $(.458)$ & $(.427)$ & $(.481)$ & $(.487)$ & $(.470)$ & $(.447)$ & $(.458)$ & $(.427)$ & $(.479)$ & $(.486)$ & $(.468)$ \\
\hline \multirow[t]{2}{*}{ Some College } & .210 & .217 & .198 & .177 & .183 & .169 & .220 & .227 & .209 & .179 & .186 & .170 \\
\hline & $(.407)$ & $(.413)$ & $(.399)$ & $(.381)$ & $(.386)$ & $(.375)$ & $(.414)$ & $(.419)$ & $(.406)$ & $(.383)$ & $(.389)$ & $(.376)$ \\
\hline \multirow[t]{2}{*}{ College } & .081 & .068 & .101 & .080 & .065 & .099 & .088 & .074 & .108 & .086 & .070 & .107 \\
\hline & $(.273)$ & $(.252)$ & $(.301)$ & $(.271)$ & $(.247)$ & $(.299)$ & $(.283)$ & $(.261)$ & $(.310)$ & $(.281)$ & $(.255)$ & $(.309)$ \\
\hline
\end{tabular}

Note: Statistics are calculated using cross section sample weights. Standard deviations are in parenthesis. Number of observations vary by variable and sample. 
Table 8: Sources of Advantageous Selection: Predicting Medical Expenditure Using Only MCBS No Medigap Observations

\begin{tabular}{|c|c|c|c|c|c|c|c|c|c|c|c|c|}
\hline \multicolumn{4}{|c|}{ Coefficient Estimate of Pred. Exp./10,000 } & \multicolumn{8}{|c|}{ Conditioning Variables } & \multirow[b]{2}{*}{ \# obs. } \\
\hline & A & 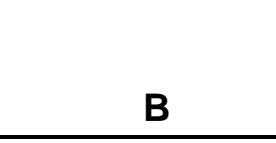 & C & risk tol. & $\begin{array}{c}\text { pred. } \\
\text { var. }\end{array}$ & $\begin{array}{l}\text { risk_tol }^{*} \\
\text { pred. } \\
\text { variance }\end{array}$ & educ. & inc. & cogn. & $\begin{array}{l}\text { long. } \\
\text { expec. }\end{array}$ & $\begin{array}{l}\text { financial } \\
\text { planning } \\
\text { horizon }\end{array}$ & \\
\hline \multicolumn{13}{|c|}{ Panel A: First Definition of Medigap } \\
\hline (1) & $-.0391(.000)$ & $-.0558(.001)$ & $-.0574(.116)$ & $\mathrm{N}$ & $\mathrm{N}$ & $\mathrm{N}$ & $\mathrm{N}$ & $\mathrm{N}$ & $\mathrm{N}$ & $\mathrm{N}$ & $\mathrm{N}$ & 9973 \\
\hline (2) & $\ldots$ & $-.0558(.001)$ & $-.0570(.118)$ & Y & $\mathrm{N}$ & $\mathrm{N}$ & $\mathrm{N}$ & $\mathrm{N}$ & $\mathrm{N}$ & $\mathrm{N}$ & $\mathrm{N}$ & 3467 \\
\hline (3) & $\ldots$ & $-.0301(.162)$ & $.0393(.121)$ & Y & $\mathrm{Y}$ & Y & $\mathrm{N}$ & $\mathrm{N}$ & $\mathrm{N}$ & $\mathrm{N}$ & $\mathrm{N}$ & 3467 \\
\hline (4) & $\ldots$ & $-.0234(.281)$ & $.0508(.063)$ & Y & $\mathrm{Y}$ & Y & Y & $\mathrm{N}$ & $\mathrm{N}$ & $\mathrm{N}$ & $\mathrm{N}$ & 3467 \\
\hline (5) & $\ldots$ & $-.0039(.843)$ & $.0636(.060)$ & Y & Y & Y & Y & $\mathrm{Y}$ & $\mathrm{N}$ & $\mathrm{N}$ & $\mathrm{N}$ & 3467 \\
\hline (6) & $\ldots$ & $\ldots$ & $.0758(.049)$ & Y & $\mathrm{Y}$ & Y & Y & $Y$ & $Y$ & $\mathrm{~N}$ & $\mathrm{~N}$ & 1696 \\
\hline (7) & $\ldots$ & $\ldots$ & $.0781(.055)$ & Y & $\mathrm{Y}$ & Y & Y & $\mathrm{Y}$ & Y & $\mathrm{Y}$ & $\mathrm{N}$ & 1695 \\
\hline (8) & $\ldots$ & $\ldots$ & $.0783(.061)$ & $Y$ & $\mathrm{Y}$ & $Y$ & $Y$ & Y & $\mathrm{Y}$ & $Y$ & $\mathrm{Y}$ & 1659 \\
\hline \multicolumn{13}{|c|}{ Panel B: Second Definition of Medigap } \\
\hline (9) & $-.0534(.000)$ & $-.0754(.000)$ & $-.0776(.022)$ & $\mathrm{N}$ & $\mathrm{N}$ & $\mathrm{N}$ & $\mathrm{N}$ & $\mathrm{N}$ & $\mathrm{N}$ & $\mathrm{N}$ & $\mathrm{N}$ & 11866 \\
\hline$(10)$ & $\ldots$ & $-.0754(.000)$ & $-.0771(.022)$ & Y & $\mathrm{N}$ & $\mathrm{N}$ & $\mathrm{N}$ & $\mathrm{N}$ & $\mathrm{N}$ & $\mathrm{N}$ & $\mathrm{N}$ & 4295 \\
\hline$(11)$ & $\ldots$ & $-.0405(.060)$ & $.0224(.398)$ & Y & $\mathrm{Y}$ & $\mathrm{Y}$ & $\mathrm{N}$ & $\mathrm{N}$ & $\mathrm{N}$ & $\mathrm{N}$ & $\mathrm{N}$ & 4295 \\
\hline$(12)$ & $\ldots$ & $-.0273(.212)$ & $.0444(.130)$ & Y & Y & Y & Y & $\mathrm{N}$ & $\mathrm{N}$ & $\mathrm{N}$ & $\mathrm{N}$ & 4295 \\
\hline (13) & $\ldots$ & $-.0069(.726)$ & $.0560(.121)$ & Y & Y & Y & Y & $\mathrm{Y}$ & $N$ & $\mathrm{~N}$ & $\mathrm{~N}$ & 4295 \\
\hline (14) & $\ldots$ & $\ldots$ & $.0683(.087)$ & Y & $\mathrm{Y}$ & Y & Y & $Y$ & Y & $\mathrm{N}$ & $\mathrm{N}$ & 2146 \\
\hline (15) & $\ldots$ & $\ldots$ & $.0694(.089)$ & Y & $\mathrm{Y}$ & Y & Y & $\mathrm{Y}$ & Y & $\mathrm{Y}$ & $\mathrm{N}$ & 2143 \\
\hline$(16)$ & $\ldots$ & $\ldots$ & $.0709(.093)$ & $Y$ & $\mathrm{Y}$ & $Y$ & $Y$ & $\mathrm{Y}$ & $Y$ & $\mathrm{Y}$ & $\mathrm{Y}$ & 2103 \\
\hline
\end{tabular}

Note: $p$-value in parenthesis. All regressions include controls for female, a third order polynomial in age-65 and State. 
Table 9: Sources of Advantageous Selection: Predicting Medical Expenditure Using All Observations in MCBS

\begin{tabular}{|c|c|c|c|c|c|c|c|c|c|c|c|c|}
\hline & \multicolumn{3}{|c|}{ Coefficient Estimate of Pred. Exp./10,000 } & \multicolumn{8}{|c|}{ Conditioning Variables } & \multirow[b]{2}{*}{ \# obs. } \\
\hline & 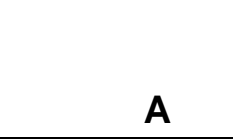 & 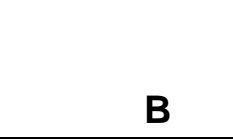 & C & $\begin{array}{l}\text { risk } \\
\text { tol. }\end{array}$ & $\begin{array}{c}\text { pred. } \\
\text { var. }\end{array}$ & $\begin{array}{l}\text { risk_tol* }^{*} \\
\text { pred. } \\
\text { variance }\end{array}$ & educ. & inc. & cogn. & $\begin{array}{l}\text { long. } \\
\text { expec. }\end{array}$ & $\begin{array}{l}\text { financial } \\
\text { planning } \\
\text { horizon }\end{array}$ & \\
\hline \multicolumn{13}{|c|}{ Panel A: First Definition of Medigap } \\
\hline (1) & $-.0275(.004)$ & $-.0519(.002)$ & $-.0465(.167)$ & $\mathrm{N}$ & $\mathrm{N}$ & $\mathrm{N}$ & $\mathrm{N}$ & $\mathrm{N}$ & $\mathrm{N}$ & $\mathrm{N}$ & $\mathrm{N}$ & 9973 \\
\hline (2) & $\ldots$ & $-.0519(.002)$ & $-.0461(.169)$ & $\mathrm{Y}$ & $\mathrm{N}$ & $\mathrm{N}$ & $\mathrm{N}$ & $\mathrm{N}$ & $\mathrm{N}$ & $\mathrm{N}$ & $\mathrm{N}$ & 3467 \\
\hline (3) & $\ldots$ & $-.0296(.173)$ & $.0263(.307)$ & $\mathrm{Y}$ & $\mathrm{Y}$ & $\mathrm{Y}$ & $\mathrm{N}$ & $\mathrm{N}$ & $\mathrm{N}$ & $\mathrm{N}$ & $\mathrm{N}$ & 3467 \\
\hline (4) & $\ldots$ & $-.0222(.313)$ & $.0380(.133)$ & $\mathrm{Y}$ & Y & $\mathrm{Y}$ & $\mathrm{Y}$ & $\mathrm{N}$ & $\mathrm{N}$ & $\mathrm{N}$ & $\mathrm{N}$ & 3467 \\
\hline (5) & $\ldots$ & $-.0034(.862)$ & $.0490(.091)$ & $Y$ & Y & $Y$ & Y & $Y$ & $\mathrm{~N}$ & $\mathrm{~N}$ & $\mathrm{~N}$ & 3467 \\
\hline (6) & $\ldots$ & $\ldots$ & $.0562(.068)$ & $\mathrm{Y}$ & $\mathrm{Y}$ & $\mathrm{Y}$ & Y & $\mathrm{Y}$ & $Y$ & N & $\mathrm{N}$ & 1696 \\
\hline (7) & $\ldots$ & $\ldots$ & $.0580(.074)$ & $Y$ & Y & $Y$ & Y & $Y$ & $Y$ & Y & $\mathrm{N}$ & 1695 \\
\hline (8) & $\ldots$ & $\ldots$ & $.0587(.080)$ & $\mathrm{Y}$ & $Y$ & $\mathrm{Y}$ & $Y$ & $\mathrm{Y}$ & $\mathrm{Y}$ & $Y$ & $\mathrm{Y}$ & 1659 \\
\hline \multicolumn{13}{|c|}{ Panel B: Second Definition of Medigap } \\
\hline (9) & $-.0429(.000)$ & $-.0776(.000)$ & $-.0832(.005)$ & $\mathrm{N}$ & $\mathrm{N}$ & $\mathrm{N}$ & $\mathrm{N}$ & $\mathrm{N}$ & $\mathrm{N}$ & $\mathrm{N}$ & $\mathrm{N}$ & 11866 \\
\hline (10) & $\ldots$ & $-.0777(.000)$ & $-.0827(.005)$ & $\mathrm{Y}$ & $\mathrm{N}$ & $\mathrm{N}$ & $\mathrm{N}$ & $\mathrm{N}$ & $\mathrm{N}$ & $\mathrm{N}$ & $\mathrm{N}$ & 4295 \\
\hline (11) & $\ldots$ & $-.0026(.956)$ & $-.0284(.705)$ & $\mathrm{Y}$ & Y & $\mathrm{Y}$ & $\mathrm{N}$ & $\mathrm{N}$ & $\mathrm{N}$ & $\mathrm{N}$ & $\mathrm{N}$ & 4295 \\
\hline (12) & $\ldots$ & $.0176(.695)$ & $.0140(.853)$ & $\mathrm{Y}$ & Y & $\mathrm{Y}$ & $\mathrm{Y}$ & $\mathrm{N}$ & $\mathrm{N}$ & $\mathrm{N}$ & $\mathrm{N}$ & 4295 \\
\hline (13) & $\ldots$ & $.0490(.262)$ & $.0483(.518)$ & $Y$ & $Y$ & $Y$ & $\mathrm{Y}$ & $Y$ & $\mathrm{~N}$ & $\mathrm{~N}$ & $\mathrm{~N}$ & 4295 \\
\hline (14) & $\ldots$ & $\ldots$ & $.0567(.438)$ & $\mathrm{Y}$ & Y & $\mathrm{Y}$ & Y & $\mathrm{Y}$ & $Y$ & N & $\mathrm{N}$ & 2146 \\
\hline (15) & $\ldots$ & $\ldots$ & $.0618(.402)$ & $Y$ & Y & $Y$ & Y & $\mathrm{Y}$ & $Y$ & Y & $\mathrm{N}$ & 2143 \\
\hline (16) & $\ldots$ & $\ldots$ & $.0695(.346)$ & $Y$ & $Y$ & $Y$ & $Y$ & $\mathrm{Y}$ & $Y$ & $Y$ & $Y$ & 2103 \\
\hline
\end{tabular}

Note: $\mathrm{p}$-value in parenthesis. All regressions include controls for female, a third order polynomial in age-65 and State. 
Table 10: Robustness of the Evidence of Advantageous Selection: "Medigap" Coefficients

\begin{tabular}{|c|c|c|c|c|}
\hline & $(1)$ & $(2)$ & $(3)$ & $(4)$ \\
\hline & Medigap 1 & Medigap 2 & Medigap 1 & Medigap 2 \\
\hline \multicolumn{5}{|c|}{ Panel A: Alternative Measures of Health Expenditure Risk } \\
\hline & \multicolumn{2}{|c|}{ Total Medical Expenditure } & \multicolumn{2}{|c|}{ Potential "Medigap" Expenditure } \\
\hline (1) & $\begin{array}{l}-4392.7^{\star \star \star} \\
(347.0)\end{array}$ & $\begin{array}{l}-4142.6^{\star \star \star} \\
(323.4)\end{array}$ & $\begin{array}{l}-4,454^{\star \star \star} \\
(202.2)\end{array}$ & $\begin{array}{l}-4,175^{\star \star \star} \\
(192.9)\end{array}$ \\
\hline$(2)$ & $\begin{array}{l}1937.0^{\star \star \star} \\
(257.6)\end{array}$ & $\begin{array}{l}1967.3^{\star \star \star} \\
(238.7)\end{array}$ & $\begin{array}{l}80.4 \\
(132.1)\end{array}$ & $\begin{array}{l}219.7^{*} \\
(125.3)\end{array}$ \\
\hline \multicolumn{5}{|c|}{ Panel B: Alternative Treatment of Medicare HMO } \\
\hline & \multicolumn{2}{|c|}{ Treated As Medigap } & \multicolumn{2}{|c|}{ Dropped From Sample } \\
\hline (1) & $\begin{array}{l}-4,418.5^{\star \star \star} \\
(364.8)\end{array}$ & $\begin{array}{l}-4210.8^{\star \star \star} \\
(345.6)\end{array}$ & $\begin{array}{l}-3996.8^{\star \star \star} \\
(298.7)\end{array}$ & $\begin{array}{l}-3,788.4^{\star \star \star} \\
(308.1)\end{array}$ \\
\hline$(2)$ & $\begin{array}{l}1,899.6^{\star \star \star} \\
(276.6)\end{array}$ & $\begin{array}{l}1927.9^{\star \star \star} \\
(254.7)\end{array}$ & $\begin{array}{l}2011.3^{\star \star \star} \\
(276.6)\end{array}$ & $\begin{array}{l}2108.5^{\star \star \star} \\
(278.5)\end{array}$ \\
\hline \multicolumn{5}{|c|}{ Panel C: Trimming Top $5 \%$ of the Observations } \\
\hline & \multicolumn{2}{|c|}{ Total Medical Expenditure } & \multicolumn{2}{|c|}{ Potential "Medigap" Expenditure } \\
\hline (1) & $\begin{array}{l}-1,400^{\star \star \star} \\
(183.1)\end{array}$ & $\begin{array}{l}-939^{\star \star \star} \\
(162.9)\end{array}$ & $\begin{array}{l}-1,103^{\star \star \star} \\
(94.4)\end{array}$ & $\begin{array}{l}-559.6^{\star \star \star} \\
(81.0)\end{array}$ \\
\hline (2) & $\begin{array}{l}1,673^{\star \star *} \\
(147.8)\end{array}$ & $\begin{array}{l}1,775^{\star \star \star} \\
(130.9)\end{array}$ & $\begin{array}{l}247.7^{\star \star \star} \\
(73.8)\end{array}$ & $\begin{array}{l}446.3^{\star \star \star} \\
(66.9)\end{array}$ \\
\hline
\end{tabular}

Note: All regressions are weighted by the cross section sample weight. See text and Data Appendix for the two definitions of Medigap.

Rows labelled as (1) report the Medigap coefficients from regression specifications that are the same as column (1) in Table 3, with only controls for variables that determine price. Rows labelled as (2) report the Medigap coefficients from specifications that are the same as column (1) of Table 4, which include direct health controls detailed in Data Appendix.

Robust standard error in parenthesis are clustered at individual level. *, ** and *** denote significance at $10 \%, 5 \%$ and $1 \%$ respectively. 
Table 11: Robustness of Sources of Advantageous Selection: Coefficient Estimate of Pred. Exp./10,000 (First Definition of Medigap)

\begin{tabular}{|c|c|c|c|c|c|c|}
\hline \multicolumn{7}{|c|}{ Panel A: Potential "Medigap" Expenditure as a Measure of Health Risk } \\
\hline & \multicolumn{3}{|c|}{ Imputation Method 1} & \multicolumn{3}{|c|}{ Imputation Method 2} \\
\hline & A & B & C & A & B & C \\
\hline (1) & $-.0420(.001)$ & $-.062(.001)$ & $-.0614(.109)$ & $-.0398(.003)$ & $-.0591(.003)$ & $-.0527(.148)$ \\
\hline (2) & $\ldots$ & $-.0618(.003)$ & $-.0607(.111)$ & $\ldots$ & $-.0578(.004)$ & $-.0506(.166)$ \\
\hline (3) & $\ldots$ & $-.0421(.201)$ & $.0423(.106)$ & $\ldots$ & $-.0368(.182)$ & $.0297(.311)$ \\
\hline (4) & $\ldots$ & $-.0286(.302)$ & $.0579(.056)$ & $\ldots$ & $-.0264(.298)$ & $.0361(.124)$ \\
\hline (5) & $\ldots$ & $-.0042(.901)$ & $.0665(.059)$ & $\ldots$ & $-.0037(.914)$ & $.0429(.094)$ \\
\hline (6) & $\ldots$ & $\ldots$ & $.0792(.043)$ & $\ldots$ & $\ldots$ & $.0556(.062)$ \\
\hline (7) & $\ldots$ & $\ldots$ & $.0797(.051)$ & $\ldots$ & $\ldots$ & $.0588(.064)$ \\
\hline (8) & $\ldots$ & $\ldots$ & $.0802(.057)$ & $\ldots$ & $\ldots$ & $.0647(.065)$ \\
\hline \multicolumn{7}{|c|}{ Panel B: Q90/Q10 As Measure of Expenditure Variation } \\
\hline & \multicolumn{3}{|c|}{ Imputation Method 1} & \multicolumn{3}{|c|}{ Imputation Method 2} \\
\hline (1) & $-.0391(.000)$ & $-.0558(.001)$ & $-.0574(.116)$ & $-.0275(.004)$ & $-.0519(.002)$ & $-.0465(.167)$ \\
\hline$(2)$ & $\ldots$ & $-.0558(.001)$ & $-.0570(.118)$ & $\ldots$ & $-.0519(.002)$ & $-.0461(.169)$ \\
\hline (3) & $\ldots$ & $-.0381(.196)$ & $.0338(.133)$ & $\ldots$ & $-.0317(.186)$ & $.0249(.324)$ \\
\hline (4) & $\ldots$ & $-.0275(.297)$ & $.0525(.067)$ & $\ldots$ & $-.0237(.308)$ & $.0377(.142)$ \\
\hline (5) & $\ldots$ & $-.0048(.784)$ & $.0619(.061)$ & $\ldots$ & $-.0035(.856)$ & $.0489(.094)$ \\
\hline (6) & $\ldots$ & $\ldots$ & $.0749(.051)$ & $\ldots$ & $\ldots$ & $.0562(.069)$ \\
\hline (7) & $\ldots$ & $\ldots$ & $.0769(.054)$ & $\ldots$ & $\ldots$ & $.0579(.077)$ \\
\hline (8) & $\ldots$ & $\ldots$ & $.0769(.059)$ & $\ldots$ & $\ldots$ & $.0584(.085)$ \\
\hline
\end{tabular}

Note: The included conditioning variables in each row are the same as those in the corresponding rows in Table 8 and 9. The columns A, B and C differ in their sample size. See text for explanations.

p-value in parenthesis. All regressions include controls for female, a third order polynomial in age-65 and State. 


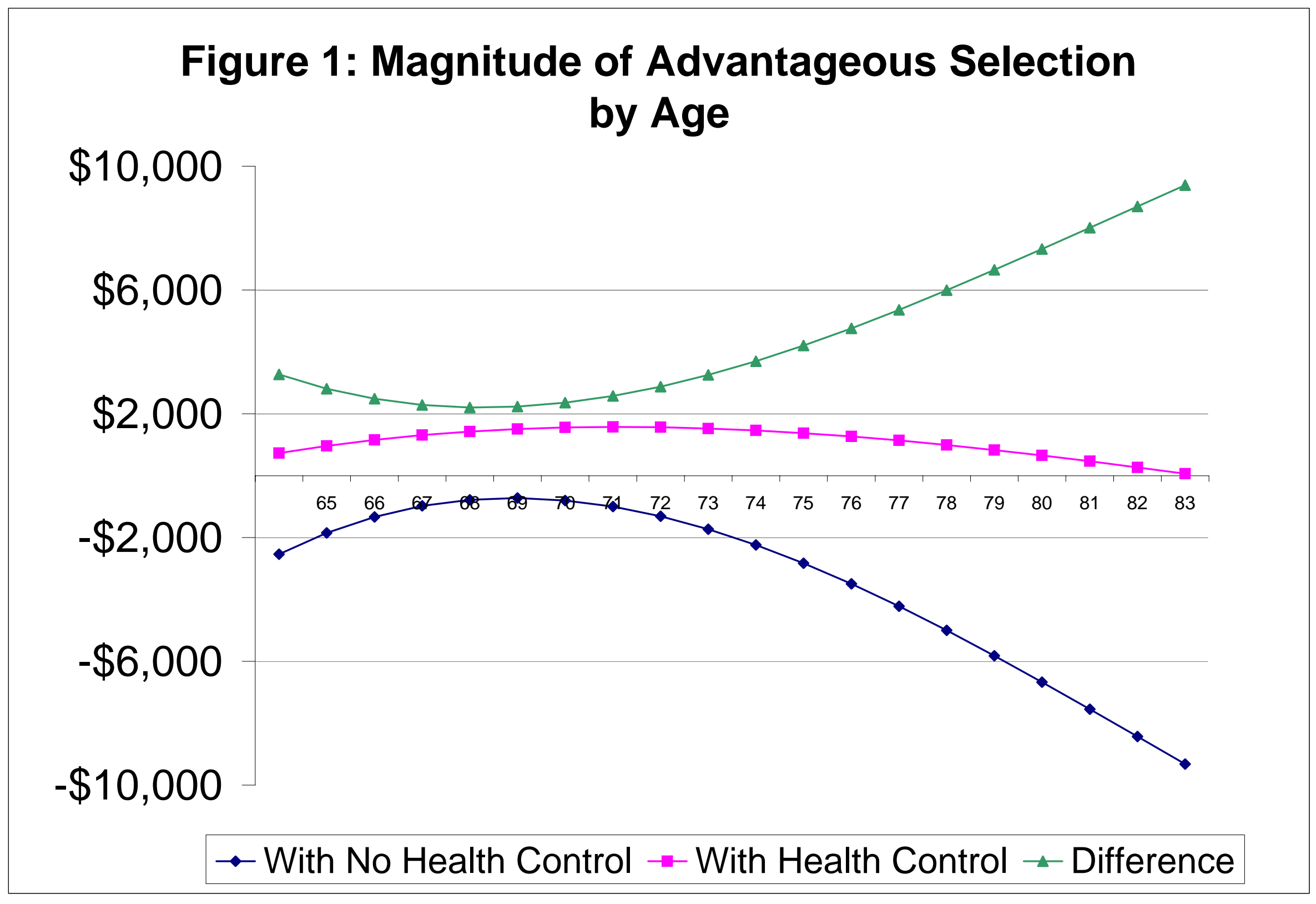




\section{DATA APPENDIX}

\begin{tabular}{|c|c|c|c|}
\hline Category & Variable & Data & Description \\
\hline $\begin{array}{l}\text { Health } \\
\text { expenditure }\end{array}$ & Total expendidure & MCBS & $\begin{array}{l}\text { Total annual health care expenditure for } 12 \text { months of the survey year. Expenditure includes data } \\
\text { from Medicare administrative files and survey responses for out-of-pocket and otherwise insured } \\
\text { expenditures. }\end{array}$ \\
\hline \multicolumn{4}{|l|}{ Insurance } \\
\hline & medicare & & Indicators for whether the respondent is covered by medicare part A and part B. \\
\hline & medigap & MCBS & $\begin{array}{l}\text { Indicator for whether repsondent, with medicare coverage also has self-purchased private health } \\
\text { insurance. Those covered by employer provided health inurance, medicaid or VA Champus } \\
\text { (Tri-care) are treated as missing. }\end{array}$ \\
\hline & & HRS & $\begin{array}{l}\text { Indicator for whether respondent, with Medicare coverage also has private health insurance that is } \\
\text { secondary to Medicare, and not purchased from a (spouse's) employer or union. Those covered by } \\
\text { employer provided health inurance, medicaid or VA Champus (Tri-care) are treated as missing. }\end{array}$ \\
\hline & medigap2 & & $\begin{array}{l}\text { Variable equal to one if medigap is equal to one, or if covered by employer sponsored health } \\
\text { insurance and pay more than } \$ 500 \text { per year in premiums. }\end{array}$ \\
\hline \multirow[t]{9}{*}{ Demographics } & race & & Indicators for self-reported black, other and non-response \\
\hline & hispanic & & Indicators for self-reported hispanic and non-response \\
\hline & education & & $\begin{array}{l}\text { Indicators for highest grade completed less than 8th grade, some high school, high school graduate, } \\
\text { some college, college graduate, at least some grad school and non-response }\end{array}$ \\
\hline & marital status & & Indicators for maried, widowed, divorced, separated and non-response \\
\hline & number of children & & The number of children the respondent has ever had. \\
\hline & income & MCBS & $\begin{array}{l}\text { Indicators for self-reported total household income in } \$ 5,000 \text { intervals from } \$ 5,000 \text { to } \$ 50,000 \text {, } \\
\text { and } \$ 50,000 \text { plus }\end{array}$ \\
\hline & & HRS & $\begin{array}{l}\text { Same indicators as above, except in this case we use reported as well as imputed values for total } \\
\text { household income. Imputations are those generated by RAND. }\end{array}$ \\
\hline & & & See http://hrsonline.isr.umich.edu/meta/rand/randhrse/randhrse.pdf for details of the imputation. \\
\hline & work status & & Indicators if currently working for pay and for non-response. \\
\hline
\end{tabular}




\begin{tabular}{|c|c|c|c|}
\hline Category & Variable & Data & Description \\
\hline \multirow[t]{9}{*}{ Health } & Self-reported & & Indicators for self-reported health excellent, very good, good, and fair. \\
\hline & Height & & Self-reported height, in inches, and height squared. \\
\hline & Body mass index & & Self-reported (weight $(\mathrm{kg})$ ) / (height $(\mathrm{m})$ squared ) \\
\hline & Ever a smoker & & Indicator if respondent has "ever smoked" tobacco \\
\hline & Current smoker & & Indicator if respondent now smokes tobacco, and for non-response \\
\hline & Diagnoses & & $\begin{array}{l}\text { Indicators for if a doctor has ever told the respondent he/she has: arthritis, high blood pressure, } \\
\text { diabetes, (non-skin) cancer, lung disease, heart attack, chronic heart disease, stroke, } \\
\text { psychiatric illness, Alzheimer's disease, broken hip and for each diagnosis, non-response. }\end{array}$ \\
\hline & Treatments & & Indicators for respondent ever having cataract surgery or a hearing aid \\
\hline & $\begin{array}{l}\text { (Instrumental) } \\
\text { activities of } \\
\text { daily living }\end{array}$ & & $\begin{array}{l}\text { Indicators for if a respondent has at least some difficulty walking } 2-3 \text { blocks, stooping, reaching } \\
\text { overhead, lifting 10lbs, dressing, walking at all, bathing, eating, getting out of a chair, using the toilet, } \\
\text { preparing meals, shopping, using the telephone, managing money and bills, and for non-response. }\end{array}$ \\
\hline & Help with IADS & & $\begin{array}{l}\text { Indicators for if a respondent receives help dressing, walking at all, bathing, eating, getting out of } \\
\text { a chair, using the toilet, preparing a meal shopping, using the telephone or managing money and bills } \\
\text { and for non-response. }\end{array}$ \\
\hline Risk attitudes & Risk Tolerance & HRS & $\begin{array}{l}\text { Estimate of risk tolerance from Kimball, Salm and Shapiro (2004), using responses to hypothetical } \\
\text { income gambles from } 1992 \text { and } 1994 .\end{array}$ \\
\hline \multirow[t]{4}{*}{ Cognition } & Word recall & HRS & $\begin{array}{l}\text { Variables recording the number of words recalled from a list of } 10 \text {, both immediately after the list was } \\
\text { read and several minutes later. }\end{array}$ \\
\hline & TICS Score & HRS & $\begin{array}{l}\text { Telephone Interview for Cognitive Status. Number of correct answers on a test of knowledge, language } \\
\text { and orientation. Questions include naming objects, vocabulary questions, and basic knowledge such } \\
\text { as the U.S. President's name. }\end{array}$ \\
\hline & Subtraction & HRS & Number of times respondent can subtract the number 7 sequentially, starting from 100. \\
\hline & Numeracy & HRS & $\begin{array}{l}\text { Number of correct answers to "word problems" of division and multiplication on topics of probability, compound } \\
\text { interest, and division of assets. Asked only in } 2002 .\end{array}$ \\
\hline $\begin{array}{l}\text { Planning } \\
\text { Horizon }\end{array}$ & Financial & HRS & $\begin{array}{l}\text { Indicators for whether the respondents most important period for planning saving and spending is } \\
\text { the next few months, the next year, the next few years, the next five to ten years, or more than } 10 \text { years. }\end{array}$ \\
\hline
\end{tabular}

